\title{
Anmeldelser
}

\section{DANMARKS KIRKEIR.}

Udgivet af Nationalmuseet. SøNDERJYLLAND ved Erik Moltke og Elna Møller. Under medvirken af Vibeke Michelsen. XX Haderslev Amt. Kbh. 1954. Gad. 924 s.

Afslutningen på 1. del af det planlagte firebinds værk om Sønderjyllands kirker er for så vidt en begivenhed af rang, som vi hernede til nu har skullet klare os med Haupts 70 år gamle Bau- und Kunstdenkmäler der Provinz SchleswigHolstein og de meget summariske oplysninger hos Trap. Savnet har for os i Sønderjylland varet så meget føligere som man fra tysk side allerede f $\varnothing \mathbf{r}$ sidste krig havde den reviderede udgave af Haupt færdig for vestkysten af Sydslesvigs vedkommende (Sydtønder 1939, Husum 1935, Ejdersted 1939), og efter krigen Flensborg og Eckernförde. At man fra dansk side har foretrukket at behandle kirkerne for sig og lade de profane bygningsværker og inventarer vente til et senere værk er vist en fornuftig ordning. Principperne for indsamling af materialet er så forskellige, og provinsmuseerne må til sin tid være direkte medvirkende ved et sådant inventarium, mens Nationalmuseets 2' afdeling naturligt har kunnet løse de komplicerede opgaver i forbindelse med kirkebeskrivelserne.

DANMARKS KIRKER er jo ikke blot et vark, men en institution, en afdeling under Nationalmuseets 2' afdeling, og snart er et kvart århundred henrundet siden det første af bindene udkom. De principper for beskrivelse og for typografisk opstilling, der i sin tid blev fastlagt, må begribeligvis følges for helhedsvirkningens skyld, hvor uundgåeligt det end er at senere tider vil skifte smag og anse andre metoder for rigtigere. Hvad det ydre angår, er værket køligt fornemt, med en konventionel elegance som vakker respekt, men ingen beundring. Ingen typografiske narrestreger, ingen fede skrifter, ingen spatiering, ingen understregning, alt så fuldendt korrekt. Det samme gør sig gældende ved illustreringen. Fotograferingen er gennemgående prima, særlis for træskulpturernes vedkommende (detaljer som dem fra Halk, pag. 459 endog helt fremragende), men ofte medf $\emptyset$ rer denne diskrete og neddaempede reproduceren at tingenes sprog forvranges, ikke mindst går det ud over kirkekunstens uimodståe- 
lige humor. Men medgis må det, at den fordel, det tyske inventarium i så henseende opnår ved at samle illustrationerne på kunsttrykpapir bag i værket, her opvejes ved det praktiske $\mathrm{i}$ at tekst og illustration f $\varnothing$ lges ad.

Hvad angår de redaktionelle principper, må de vel være så gennemprøvede $i$ løbet af de forløbne 25 år at kritik må forstumme. I sandhed må man beundre værkets redaktører for den selvbeherskelsens kunst, de $i$ deres beskrivelser lægger for dagen. Men hvor det dog liver op, når naturen går over optugtelsen og der smutter et rosende eller et fordømmende adjektiv ind $i$ kataloget. Vel ved vi at sligt kan hævne sig grumt, at hvad vi idag priser, måske fordømmes i morgen, men kirkekunsten er jo ikke blot dødt stof, der skal måles og vejes, den er liv, og skal behandles som sådant.

Et særligt intrikat emne er de til forskellige tider stedfundne restaureringer af bygninger og inventar. Hvadenten der er tale om nulevende eller fortidige restauratorer og konservatorer, må det være svært ikke at tage stilling til kvaliteten af deres arbejde. I almindelighed refereres der blot dertil, undtagelser danner f. ex. afsnittet om Vilstrup kirke, hvor det hedder:

»Ved hovedrestaureringen 1939-40 omkalfatredes inventaret $i$ kirken. Altertavle og orgel, der var forenet $i$ en smuk empireopbygning, adskiltes, og orglet flyttedes ned i vestenden tilligemed de tilhørende, svungne pulpiturer; de gamle, enkle stolestader med lave trekantgavle og dørene, der havde bidraget til at give rummet et samhørende og sluttet udseende, kasseredes ... *

Og strålende veloplagt er Elna Møllers 28 sider lange redeg $\varnothing$ relse for Starup kirkes bygningshistorie, et skarpsindigt personlig præget stykke polemik mod den tyske restaurering og rekonstruktion i årene 1909/18.

Men ellers er den strenge saglighed dominerende, og selv om bogen indledningsvis er forsynet med en omfattende fagordbog, kan særlig de arkitektoniske afsnit være hårde nok at komme igennem.

Bogen om Haderslev amts kirker indeholder et forord, der g $\phi \mathbf{r}$ rede for redaktionsprincipperne, den nævnte fagordsfortegnelse, arkivaliefortegnelse og — foruden beskrivelserne af købstads- og landsbykirkerne - en redegørelse for Sønderjyllands politiske og administrative forhold af vort historiske sam-

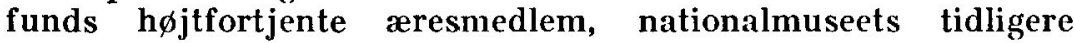
direktør, M. Mackeprang, hvem vi iøvrigt har at takke for at kirkeværkets redaktion sprang de фvrige endnu ikke behandlede 
kongerigske amter over og tog fat på Sønderjylland, der først har numrene 20-23.

Det er virkelig en bedrift direkt $\varnothing \mathbf{r}$ Mackeprang har udf $\varnothing \mathbf{r t}$ med denne kun 15 sider lange afhandling. Ingensinde er der til dato skrevet mere instruktivt og klart om det mest indviklede område $\mathbf{i}$ dansk historie.

Selv om amtsinddelingen - hvad fremgår af dr. Mackeprangs indledning - set fra et historisk synspunkt specielt for $\$ \varnothing$ nderjylland er uheldig, taler praktiske hensyn dog for den. Redaktionen f $\varnothing$ lger da osse ganske n $\varnothing j$ e Trap, begyndende med domkirken i Haderslev, byens $\emptyset$ vrige kirker samt Christiansfeld, derefter følger Sdr. Tyrstrup Herred med 7, Haderslev Herred med 9, Gram med 10, Frøs med 9 og Nørre Rangstrup med 5, $i$ alt 40 landsbykirker plus de 4 ikke mere eksisterende i Dover, Endrupskov, Højrup og Lilholt.

Praktiske hensyn ligger vel osse til grund for at den kunsthistoriske oversigt, der som en sammenfatning afslutter hvert af amtsbindene, her skydes ud til alle 4 bind for Sønderjylland foreligger, et forhold, der bevirker at de her gjorte bemærkninger kun kan opfattes som en foreløbig anmeldeise til værket i sin helhed er trykt.

De historiske indledninger, der går forud for hver kirkebeskrivelse, kunne man nok ha $\varnothing$ nsket sig mindre lapidariske, vist gerne til fordel for de tit lidt vidtløftige bygningsbeskrivelser, der f $\varnothing$ lger efter bestemmelsen af beliggenheden.

En særstilling i bogen indtager naturligvis Haderslev Domkirke, om hvilken der ikke før er skrevet nogen dansk monografi af virkeligt omfang. Bygningshistorien er skrevet af anden afdelings leder, Aage Roussel, inventar og gravstene er beskrevet af Erik Moltke og Vibeke Michelsen.

En oprindelig granitkirke fra slutningen af 1100 ' tallet, af hvilken kun kvadre i den nuværende teglstenskirke er bevarede, aflóses af det monumentale bygningsværk, der er genstand for Roussels velskrevne og klart overskuelige, godt 60 sider lange beskrivelse. Vederkvægende sammenfatninger letter den mindre arkitekturkyndiges trælsomme vandring gennem den vældige bygnings forskellige afsnit: den romanske af cistercienserne inspirerede korskirke, den senromanske hallekirke, det gotiske kor fra f $\phi$ rst i 1400-tallet, kapellerne og de mange senere tilbygninger.

Domkirkens inventar har desværre ikke bygningens internationale format. Når bortses fra de sjæeldne alanastfigurer $i$ altret, den flensborgske malmdøbefont og de særprægede sten- 
epitafier, kan resten vel anskues i sammenhæng med amtets øvrige kirkers inventar.

Af de 40 kirker på landet er de 4 (Tyrstrup, Bjerning, Jels og Vojens) nye. De фvrige fremviser talrige fællestræk m.h.t. bygningshistorien. For kors og skibes vedkommende or de alle opførte $i$ romansk tid og bygsematerialet er granitkvadre og/eller kamp (med undtagelse af frådstenskirken i Starup og tufstenskirken i Lintrup (og lidt i Fole). Romanske apsider har kun få af dem: Aller, Oksenvad, Nustrup, Skodborg, Hygum, Fole og Toftlund (og genopbygget i Lintrup). De gotiske tilbygninger, ofte af munkesten, er tårn, sakristi, våbenhus, korsarme, $\phi$ st- eller vestforlængelser. Karakteristisk er for en del kirker at tårnet anbringes i $\phi s t$ (Hjerndrup, Grarup, Halk). I nyere tid -i Frøs og i Nørre Rangstrup Herreder endog overvejende i forrige og $i$ dette århundrede - er fortrinsvis tilsat våbenhuse. Afg $\emptyset$ rende æendringer i Vedsted, Skodborg, Gram og Toftlund.

Romanske billedhuggerarbejder møder vi i portalerne i Aller og Skodborg, billedkvadre og tympaner i Hjerndrup, Grarup, Jels og Skrave. Morsomst er vel skibet i Vilstrup.

Når vi lader den ejendommelige, ufuldendte frådstenskirke i Starup ude af betragtning, gør de $\emptyset$ vrige et såre ensartet indtryk, behageligst hvor de står mest urørt, som de sinå primitive kirker i Hjerting og Tirslund. Kun kirken i Øsby har i gotisk tid gennemgået en radikal fornyelse. Den er amtets mest hфjthvælvede kirke. Den er vel osse den længste.

Til bygningsbeskrivelserne, som Elna I $\phi$ ller har aren for, hører for hver kirke en plan, gengivet $i$ forholdet $1: 300$, med signaturer for murvarkets tilblivelsestid. Yderligere et eller to exteriører af bygningerne som helhed, og — i regelen - eet interiør. Hvert afsnit er fikst afsluttet med et beliggenhedskort fra slutningen af 1700-tallet, hvor sådanne har kunnet tilvejebringes. De samlende oversigter må vi afvente med den kunsthistoriske oversigt, ikke særlig praktisk i $\emptyset$ vrigt.

Større variation byder os Haderslevkirkernes inventar. Fra romansk tid er kun døbefontene, næsten alle af granit, bevarede. Mest karakteristisk fra amtet er den såkaldte Haderslevgruppe, hvis kendingsmærke er ranken (Bjerning, i Haderslev Museum, Vilstrup, Starup og $\emptyset_{\text {sby }}$ ). Mest særpræget er den i Jegerup med bemærkelsesværdige relieffer $\mathrm{i}$ foden. Kun i Halk findes der en malmfont, magen til den i Haderslev domkirke, af samme Flensborgmester. Kunstnerisk set er vel Lintrupfonten med sine rige skulpturer amtets betydeligste. Romanske er dog osse foruden en del gravsten et par røgelseskar, hvoraf to fra $\emptyset$ sby og 
Hygum i Nationalmuseet, og et fra Gram i Flensborg Museum. Men heller ikke det gotiske inventar har tiden reret god ved. Middelalderkirkens fornemste pryd, altertavlen, med hvilken kirkekunsten kulminerede $i$ tiden indtil renæssancen, er $i$ Haderslev amt repræsenteret ved eksklusive, men meget få eksemplarer. Man bemærker at omflytningen af højaltrene hyppigt forekommer, at kirkerne - som regel til skade - har anskaffet sig nyt og overladt et fattigere sogn sit gamle alter. Således har 12 af de 40 Haderslevkirker altre fra tiden efter 1800 (foruden Gl. Haderslev), Domkirken og Lintrup har nykonstruerede altre med karbuekrucifikser som prydelse.

Kun 8 af kirkerne har bevaret de oprindelige (sen) gotiske altre, nemlig Hjerndrup (fra Tyrstrup), Halk, (med renæssanceramme), Hammelev, Vedsted (fra Øster Løgum), Nustrup, Skrydstrup (nyere skab), Branderup og Tirslund, alle fra tiden mellem 1450 og 1525. Fem af disse kirker har - sammen med 14 andre - yderligere enkelte figurer eller figurgrupper fra tidligere $h \phi j-$ og sidealtre, Halk endog et helt sidealter. Hertil skal af det gotiske inventar så føjes de ret hyppigt forekommende korbue- og processionskrucifikser (henved halvdelen af kirkerne), der i nogle tilfælde udgør det ældst eksisterende træinventar overhovedet, således det i Fjelstrup, der betegnes som et af de bedste middelalderlige krucifikser i Danmark (o. 1250). En lignende alder har krucifikserne i Oksenvad og Jegerup, mens St. Hjælper-krucifikset i Nustrup, som det eneste i det nuværende Danmark (fra slutningen af 1400-tallet), nok tør karakteriseres som amtets st $\phi$ rste attraktion hvad kirkeinventar angår.

Er os end lidet levnet fra den gotiske storhedstid, er der perler iblandt. Her skal kun nævnes den i så mange henseender rige Halk kirke. Altertavlen her er et lybsk arbejde af højeste kvalitet. Specielt er de 18 personer under korset $(9$ »gode « og 9 »onde\&) levende kunstværker som intet $\mathrm{i}$ hele landsdelen kan overgå. Stilistisk renere er amtes andet pragtstykke i Nustrup kirke, der har sin gotiske skabstavle intakt. Midtskabets figurgruppe er vel amtets talrigeste (40). Skæringerne er mere uensartede end i Halk-tavlen, og der er i højere grad lagt an på helhedsvirkningen. Fløjenes figurer - der er udf $\phi r t$ af en anden kunstner end den, der har gjort midtergruppen - er vurderet højt. De udg $\phi \mathbf{r}$ hver for sig et individualistisk kunstværk.

På de mange bevarede brudstykker, hvoraf en del befinder sig i museer i København, S $\varnothing$ nderborg, Flensborg og Slesvig, findes yderligere bekræftelse på gotikkens høje standard. I Fr $\emptyset-$ 
rup er der halvdelen af en midtskabsgruppe, forestillende »de gode«, henført til den såkaldte »Herslev-mester«, et af de få arbejder fra amtets kirker, der med nogenlunde sikkerhed har kunnet føres hen til et bestemt værksted. - Landesmuseums Golgata-relieffer fra Vonsbæk, der fra tysk side har været henført til Lübeckmesteren Henning von der Heide, tillagges her den samme (anonyme) mester der har gjort den ovennævinte Halk-tavle, og en Anna Selvtredie figur fra samme kirke (nu i Nationalmuseet), en opfattelse der synes godt underbygget, hvor rart det end havde været om man havde haft navnet på amtets bedste billedsnider. - Til de større ting hører osse de 12 apostelfigurer fra Jegerups tidligere højaltertavle, som skal gå helt tilbage til tiden o. 1400 og dermed være de aldste altertavlefigurer $\mathrm{i}$ hele landet. De repræsenterer den bertramske »blide stil«, en nedertysk retning fra slutningen af 1300-tallet. - En biskop fra et sidealter i Hjerting (c. 1500) og apostelrakken fra højalteret i Bevtoft sammen med den i samme kirke, mesteren for de lybske stenmadonnaer tilskrevne Maria med Barnet (c. 1475) må som det sidste anbefales kirkekunstens elskere som mål for den pilgrimsfard kirkeværket animerer til.

Det er imidlertid ikke gotikken der præger Haderslev anits kirker. Hvad vi kan iagttage på Halks eksklusive altertavle, hvor amtets bedste gotiske midterskab er indfattet $i$ en senrenæssance-ramme (ca. 1630), er i sig selv typisk for hele distriktet, ja, vel for Sønderjylland med. Men intet sted støder to tidsaldres stilarter brutalere sammen end her, og intet sted fornemmer man stærkere renæssancens kunstneriske afmagt, og det endda på trods af at Halk-tavlen er et såre dygtigt arbejde. Renæssancens værksteder, der i modsætning til gotikkens gerne er hjemlige, lader sig ganske anderledes let erkende hernede. Halk-tavlen er beslægtet med tilsvarende arbejder i Astrup og Oksenvad.

I 17 af amtets kirker er renæssancen altertavlens stil og udg $\varnothing \mathbf{r}$ dermed den største gruppe. Grundtypen forefindes i Moltrup, i Jegerup (egl. fra $\emptyset$ sby), i Vojens (egl. fra Starup), i Stepping, i Hoptrup, alle fra første fjerdedel af 1600-tallet. I storfeltet, der er flankeret af $s \phi j l e r$, er indsat et gerne senere malet nadver- eller korsfæstelsesbillede. De fløjlignende sidestykker er oftest frie, og ligeledes rammer om malerier med bibelske motiver. Over storfeltet er der en trekantgavl, over sidestykkerne voluttopstykker. På postamentfremspringene sidder udskårne hoveder med alle mulige narrestreger. Arkader med kanneleret rammeværk, en uendelighed af ædelstensbosser, båndslyng, karya- 
tider og putter, »vinger« i fortsættelse af sidegavlene med kartoucher o.s.v., er de faste elementer disse strengt ornamentale altre er opbyggede af. Man kan ikke sige at Haderslev-snedkrene i deres renæssance-altertavler nåede over jævnmålet. Bedre er vel et par udenamtsarbejder i Gram og i Skodborg af Varde-mesteren Jens Oluf sen.*)

Skal et enkelt af Haderslev amts renæssancealtre fremhæves, må det blive Hjertings (opr. fra Hygum). Det dækker helt det lille kors $\phi$ stvæg, beregnet til en større kirke som det var. Som karyatider fungerer fire festlige, respektløst udskårne evangelister, anbragt på en kraftig beslagværksdekoreret postamentbjalke, indrammende de tre malerier, nadveren, $\gg$ tro og $\gg$ håb de sidste fra tiden. Topstykket med en Golgatascene har samme bredde som storfeltet og er flankeret af to kraftige hermer. Hele arbejdet $i$ al sin landlighed er så gedigent og redeligt og trods sine mangfoldige detaljer så uniformt at det kan hævde sig blandt renassancens bedste.

Prxdikestolene i amtet er forholdsvis ensartede. Medtar vi domkirken og Gl. Haderslev, fordeler de sig sáledes: renæssance 16 , barok ( $\mathrm{mm}$ ) 14, nye 12 .

Her synes at være tale om helt andre snedkere, kvaliteten er for renæssancearbejderne såre god, ja i et enkeit tilfælde vel uovertruffen noget andet sted i hele Sønderjylland. Bemærkbart er det at der er 5 (7) stole fra tiden f $\phi \mathbf{r} 1575$ i behold: Stepping, der regnes for Sønderjyllands ældste, fra 1558, Halk og Øsby fra 1559, Nustrup og Tirslund (omend omarbejdede) fra 0.1575 (samt et par foldeværksstole fra Toftlund (der fungerer som degnestol nu) og Hammelev, hvis fyldinger er indsat $i$ alterbordet.

Prædikestolen i $\emptyset$ sby, der har værkstedsfællesskab med Tyrstrups tidligere, og tre af de forannæunte, er skåret af en overmåde smagssikker kunstner. Endsk $\not$ nt den indeholder de vanlige renæssanceelementer (rundbuede arkader, kerubhoveder, akantus, s $\varnothing$ jler, tandsnit, perle- og æggestave) er de anvendt så behersket at arbejdet fornemmes som sydligt $k \phi b s t a d s a r b e j d e$. I midtfeltets pilastre er fremstillet som dobbeltkaryatider Adam orer Eva, og fanden under sin oldemor. Det er vist f $\varnothing$ rste gang den dame træffes i dansk kirkekunst!

I den $\varnothing$ stlige del af amtet, i Toftlund, har en Løgumklostersnedker skabt en noget bastant kopi af Tønder-stolen, og det să

*) Carsten Petersens teori om at disse mange ret ensartede altertavler skulle være udf $\emptyset$ rt af Hans Dreyer - Sønderjydske Aarb $\emptyset g e r$ 1927 - synes ikke godtaget af kirkeværket. 
sent som 1654, men endnu besynderligere er det at pradikestolen i Branderup fra 1725 synes skåret efter T $\phi$ nder-normens læst.

Barokkens prædikestole er med undtagelse af domkirkens (fra 1636) mindre særprægede. Mellem Hjerndrups, Røddings, Lintrups og Hjertings synes der at være nær sammenhæng, som mellem Allers og Hammelevs. Et par er udefra, Hoptrups fra et Flensborg- og Vilstrups fra et Middelfart-varksted.

I Fros og Nr. Rangstrups herreders kirker har man ladet pulpiturerne urorte $\mathrm{i}$ forholdsvis mange af kirkerne. De fleste er fra 1700-tallet, men $\emptyset$ ster Lindets allerede fra 1679. Kun een kirke $i$ amtet har loftsdekoration, Åstrup, med et kassetteloft fra $\mathbf{1 6 7 5}$.

Takket være gamle bestemmelser om at guldsmedene skulle stemple deres arbejder med by- og mestermarke, er det os muligt i højere grad end for det $\phi$ vrige kirkeinventars vedkommende at afgøre hvilke håndvarkere der har udfort Haderslev-kirkernes solvbestand. Som helhed betragtet er bestanden lidet original og indeholder ingen pragtstykker eller sarprægede arbejder, der hæver dem over landsdelens $\phi v r i g e$ arbejder. Men de giver en udmærket illustration til særlig det haderslevske guldsmedehåndværks udvikling gennem to århundreder.

Fra romansk tid er os intet overleveret, og fra gotisk tid kun lidet, og oftest i forbindelse med omarbejdede kalke. Intakt er alene en i Landesmuseum i Slesvig opbevaret, fra Marianerkapellet i domkirken stammende kalk med årstal 1506. Den har den gængse gotiske form, sekskantet fod og skaft, flad knop med rudebosser, i hvilke $i$ minuskler er ind graveret det vanlige Ihesvs. Lidt ældre er alterkalken i Stepping, hvor bageret, ligesom på de to indbyrdes beslagtede kalke i Vilstrup og Vonsbak fra tiden o. 1500, er fornyet. Og endelig er knoppen i Vedsteds kalk rent gotisk (resten senere). Osse i de beslægtede kalke i Frørup, Jegrerup og Fjelstrup er der benyttet dele af ældre, gotiske, ligesom senere renæssancens guldsmede direkte kopierer gotikken (det pånittede krucifiks på Hammelev-kalken, der med sekstunget fod er et renæssance-arbejde, men f $\phi r s t$ udf $\phi r t$ i 1650'erne - af samme mester som Fjelstrups). Kalkene i Hjerndrup og Magstrup, der må være udf $\varnothing$ rt i samme værksted (men usignerede), har trods renæssancefod stærke gotiske trak, uden at der vel derfor er grund til at formode at knopperne med stavværksgennembrudte tunger er ældre og andet end kopiering.

Men alt $i$ alt giver det overleverede os intet virkeligt indtryk af den forreformatoriske guldsmedekunst. Ikke engang arkivalsk lader kirkens rigdom på adelmetaller sig spore langere. Hvad der (p. 141) refereres til af klenodier, tilhørende Marianerkapellet i domkirken, er kun en brøkdel af hvad der har varet. Edel- 
metallernes konstante værdi og genstandenes omsmeltelighed i forbindelse med menneskelig griskhed forklarer hvorfor alle spor af højmiddelalderens rige guldsmedekunst er udslettede.

Med de ovennævnte sengotiske kalke udg $\emptyset \mathbf{r}$ det samlede antal s $\varnothing$ lvgenstande $i$ amtets kirker henved 150, hvoraf næsten halvdelen kan tilskrives guldsmede fra Haderslev. Typerne er: alterkalk og disk, vinkande og oblatæske, berettelsessæt, en enkelt klingpung og 3 brudekroner. Af vinkanderne har kun de 6 kunsthistorisk interesse.

Forholdsvis få af arbejderne er indkøht i Tyskland, nemlig 3 oblatæsker, hvoraf en fra Hamborg i domkirken, to fra Augsburg i Vilstrup og i Nustrup, samt en kalk i domkirken fra K $\phi-$ nigsberg og en brudekrone fra Halk (i Haderslev Museum) fra Altona, resten er fra landsdelen og det фvrige land, først og fremmest Tønder med en halv snes genstande $i$ den vestlige del af amtet, Løgumkloster med 4 (herunder den fejlagtig Høvring i Randers tillagte brudekrone i Vilstrup, som mả være udf $\phi r t$ af Christopher Hiller), Åbenrå med 4 (deriblandt amtets eneste sølv-klingpung af Rudolph Nielsen, i Agerskov) - og så Kolding, Ribe og Ringk $\varnothing$ bing. Starups sygekalk, hvis initialer IM blot anf $\varnothing$ res, tør vel tillægges S $\phi$ nderborgmesteren Jürgen Matzen Jürgensen?

Ganske få uopløselige signaturer er forefundet, således IHP og GS på kalkene i Grarup og Øsby samt IM på sygekalk og -disk i Tyrstrup, og HCL på brudekrone i Hoptrup. Mesterbestemmelserne, der er baserede på B $\emptyset$ jes fortegnelse, giver almindeligvis ingen anledning til kritik. Usikkert er det dog at henfore sygekalkene i Vilstrup og Hammelev med mærket PP til Peter Petersen i Tønder, af hvem ellers intet kirkes $\varnothing l v$ kendes, når det om en ganske tilsvarende ( $o g$ tidligere) af Claus Otzen i Åstrup hedder: Samme populære (!) kalkform udf $\varnothing$ rtes af bl. a. Peter Petersen i Tønder ...., hvor der altså er grund til at formode at typen er skabt af Otzen, altså i Haderslev, der osse har en Peter Petersen, samtidig med Tønders, som vel snarere må antages at ha efterlignet Åstrup-kalken. I nedenstående liste over de Haderslev-guldsmede, der har udf $\varnothing$ rt s $\emptyset$ lvarbejder i Haderslev amts kirker, er disse to arbejder da tillagt PP i Haderslev, selv om endnu ingen afg $\phi$ rende bevisligheder for teorien foreligger. Mestrene er næunt i den rækkefølge de angives i hos Bøje.

Thomas Hansen Bahr: 2 vinkander i Domkirken 1677 og 1687 Kalk og disk i Fjelstrup 1655.

Kalk i Vedsted 1679.

Kalk i Hammelev c. 1650.

Kalk i Jegerup 1653. 
Mathias Mogensen: $\quad$ Kalk og disk i Aller 1712.

Sygekalk i Hoptrup 1740.

Kalk i Astrup 1711.

Kalk i Moltrup 1720.

Kalk i Oksenvad 1724.

Disk til sygekalk i Agerskov 1743.

Iver $R$. v. Barm: $\quad$ Oblatæske i $\emptyset$ ster Lindet 1762.

Oblatæske i Fole 1767.

Wolf Petersen: Oblatæske i domkirken 1754 (rep.)

Bæger til kalk i Hjerting 1746.

Ske i domkirken (1777).

Claus Otzen:

Disk i Gl. Haderslev 1780.

Sygekalk i do. 1773.

Disk i Halk 1778.

Oblatæske i $\emptyset$ sby 1772.

Sygekalk i Åstrup 1766.

Disk i Moltrup.

Sygekalk i Moltrup 1773.

Sygekalk i Oksenvad 1759.

Kalk i Jels 1759.

Sygekalk i Vedsted.

Kalk og disk i Nustrup 1784

Jens Jensen Due: $\quad$ Bæger til kalk i Tyrstrup 1775.

Peter Petersen: $\quad$ Kalk i Hoptrup og oblatæeske 1790.

Sygekalk i Vilstrup 1785.

Sygekalk i Hammelev 1784.

Martin Hinr. Petersen: $\quad$ Sygesæt og oblatæske i Øsby ca. 1800.

Kalk i Sommersted 1810.

Sygekalk og disk i Bevtoft 1807

Joh. Ad. Müller:

Sygekalk i Fjelstrup 1815.

Vinkande i Vilstrup 1818.

Thomas Larsen: Kalk og oblatæeske i Halk 1812.

Sygekalk i Skodborg 1816.

Sygekalk og disk i Hygum (1812).

Rep. af kalk i Jegerup.

Fr. Wilh. Sievers:

Sygekalk i Øster Lindet 1837.

Joh. Peter Rode:

Disk i Hoptrup 1837.

Kalk i Rødding 1829.

Bæger på sygekalk i Magstrup.

Kalk i Skrave 1829. 
Wolfgang Petersen: Disk i domkirken.

Rep. af oblatæeske i Starup 1839.

Dåbsfad i Øsby 1839 .

Vinkande i Åstrup 1832.

Kalk, disk og vinkande i Hygum 1839.

Kalk og oblatæeske i Toftlund 1844.

Joh. Wilh. Nissen: Sygesat i Aller 1865.

Rep. af kalk i Øsby 1865.

Disk i Vedsted.

Rep. af kalk i Skrydstrup.

Kalk i Øster Lindet 1856 .

Kirkeværket giver - som det ses - et omfattende supplement til B $\varnothing$ je og - understreget med talrige illustrationer - et solidt bidrag til håndvarkets historie. Med kirkes $̧$ lvet må de gamle mestre formodes at ha gjort sig mest umage, og håndværkets standard lader sig sikkert aflæse i netop denne genre. Den kunstneriske kraft den kirkelige træskærerkunst fra senmiddelalder og renæssance lagger for dagen, fornemmes ikke her, men med sin soliditet og gedigenhed er sølvarbejderne det sidste udtryk for betydeligt kunsthåndværk i kirkens tjeneste.

Meget mere burde fremhæves af den righoldige inventarfortegnelse, men det får blive ved et par antydninger: Klokkerne, hvor man forbavses over at der trods udrensningen under forste verdenskrig findes romanske klokker fra o. 1200 i Hjerndrup og i Skrydstrup, og gode renæssanceklokker i Stepping og Magstrup, for ikke at glemme messeklokkerne i Agerskov og Tirslund, alterstagerne ợ dảbsfadene, der spænder over tidsrummene sengotik, renæssance og barok, hvor de er bedst, og - til sidst - gravminderne, epitafier og gravsten, hvor man mindre forbavses over den høje kvalitet $i$ domkirkens store mangde end over $i$ en landsbykirke som $\emptyset$ sby at finde forfinede barok- og rokokoepitafier sammen med romanske gravsten af bedste kvalitei.

I denne sammenhang $t \phi r$ måske fremsattes et par kritiske bemarkninger til det system eller rettere mangel pã system der benyttes ved citering af gravinscriptioner, f. ex. pag. 199. Hvor ligger »Coppenhagen«? Pag. 202: Hvor Kekenis? Pag. 231: Hvor Alt Hadersleben? Pag. 313: Hvor Sautrup på Sundeviid? Enten skal vel teksten citeres ordret eller på dansk.

Ja, en begivenhed er udgivelsen af dette værk. Vi har fra dansk side så meget der skal indhentes med hensyn til udforskningen af $S \phi$ nderjyllands historie. Der er så meget af det gamle der skal gøres om, der er så mange nye synspunkter der venter på at se dagens lys. Med DANMARKS KIRKER fornemmer man at noget for en gangs skyld er gjort fardigt. Der er hold på det, 
og der er stof for en legion af lokalhistorikere, råmateriale til metre af nye historiske arbejder. Og der er animering til et utal af monografier. Og hvor får vore lokale museumsfolk travit, når de skal redde alt det der ifølge bogen ligger på kirkelofter og i præstegårde og som b $\phi$ r reddes, mens tid er.

Disse spredte bemærkninger skal afsluttes med en hyldest til manden bag det hele, redaktør Erik Moltke, hvis flid og grundighed, hvis elskværdighed og hjælpsomhed er kendt ud over den hele landsdel, i hvis kirker han har varet en kær gæst. Vi må $\emptyset$ nske ham held til på kortest mulig tid at få mammutværket færdig. Første hæfte af Tønder-bindet er trykt, og vi venter spændt.

Sig. Schoubye.

\section{Marten Refslund Poulsen: Erindringer II.}

Genforeningen i Nordslesvig. (Det Danske Forlag 1957). 320 sider.

Med en let omskrivning af Martin A. Hansen kan vi sige, at vi i Nordslesvig har varet rige på »episke « mand, bærere af den lange erindring og præget af frodig fortælleglæde. Nicolai Svendsens og Marten Refslund Poulsens levnedsskildringer er vidner herom fra de senere år. Levende optaget af dagens spørgsmål som de hegge er, har de $\mathbf{i}$ deres tilbageblik over et langt livs brogede hændelser ikke blot delagtiggjort os i disse, men tillige givet samtiden glimt af vore forfadres livsrytme, den århundredgamle tradition, som er gået under i vor tid og helt vil være udslukt med disse fortallere.

Refslund Poulsens 2. erindringsbind er fort frem til 1952 og skildrer således i egentligste forstand vor egen tid fra afstemningen til i dag, arligt, usminket og højst personligt. Det er iklie forfatterens agt at skrive tidsalderens historie, han understreger flere steder, at han vil give sine egne oplevelser. Vi får dem, set gennem et temperament os med navns navnelse af de mennesker, han har haft med at gore. Men da han har været med i så meget og har taget så aktivt del i landsdelens liv, bliver hans erindringer tillige et stykke samtidshistorie af hoj rang.

De f $\varnothing$ rste halvhundrede sider omhandler afstemningstiden og genforeningen. Derefter folgher hogens fyldigste afsnit på ca. 140 sider om mellemkrigstidens indlevelsesproces og kriserne, med tyngdepunkt $i$ de mange $\phi k$ onomiske og andre praktiske foretagender, hvor der blev gjort brug af Refslund Poulsens arbejdskraft. Et halvt hundrede sider er viet skildringen af hjemliv og personer i Bovlund, slægt og venner, og de sidste firsindstyve sider behandler bescettelsestiden og problemerne efter 1945 , herunder isæer Sydslesvig-roret. 
Det er ikke at vente, at redegørelsen for afstemnings- og genforeningstiden skulle f $\varnothing j \mathrm{je}$ nyt til vor viden om denne periode. Det forekommer mig, at forfatteren - hans stærke temperament og aktive deltagelse $i$ kampen om grænsen taget i betragtning redeligt stiller de stridende opfattelser op og g $\phi$ r ret og skel til begge sider. Selv om jeg kun har oplevet disse begivenheder som stor dreng, mærkes dønningerne nu så længe efter i mit sind. De følelsesmæssige bindinger til mit barndomshjem giver mig forståelse for kampen for Mellemslesvig, men såvel principielt som også på baggrund af tildragelserne i det siden da forlőbne åremål må det erkendes, at H. P. Hanssens linje var den rigtige. Derimod anser jeg hans indtræden i ministeriet Zahle som uklog og måden, hvorpå det skete, stødende over for Vælgerforeningens bestyrelse. I dette forhold ser jeg hovedårsagen til, at det ikke blev H. P. Hanssen, der holdt hovedtalen på Dybbøl, men grev o. D. Schack.

Meget st $\emptyset \mathrm{v}$ hvirvledes op i kampens hede, noget af det kunde og burde være undgået, »men ellers var det rimeligt, at der blev kæmpet. For det var ikke en Storm i et Glas Vand. Det var et for Danmark livsvigtigt Spфrgsmål. Hvis det ikke havde grebet dybt og sat Sindene i stærk Bevægelse, så havde det været en folkelig Mangel«. Med disse kloge og velafvejede ord giver Refslund Poulsen de mange år efter sin vurdering af grænsestriden, hvis følgevirkninger også han personligt fik at mærke.

To steder i dette af snit af bogen siger forfatteren, at de kongerigske Flensborg-folk (ved deres private udsendinge til fredskonferencen) selv var skyld i den uheldige bestemmelse om de udenforstående tyske tilrejsendes stemmeberettigelse. (s. 46 og s. 54). Det kan næppe være rigtigt. Det er indf $\varnothing j$ jelsen af den 3. afstemningszone, der skyldes de næunte kredse. Slettelsen af rømningsområdet syd for 2. zone skyldes ubehændighed eller forglemmelse fra dansk side. Men slettelsen af den afgorende passus vedrorende de stemmeberettigede - - og udvist af de daværende magthavere « - tillægges som bekendt de sejrende magters juristkommission og opfattes som en redaktions- eller korrekturfejl.

Det store afsnit om de praktiske forholdsregler og $\emptyset$ konomiske foranstaltninger som $f \phi$ lge af genforeningen og kriserne er bogens vagtigste og er højinteressant læsning. Det er ikke altsammen lige let tilgængeligt, hvilket især gælder beretningen om Nordslesvigsk Kreditforenings endeligt og organiseringen af Sønderjyllands Kreditforening. Som helhed giver det et imponerende billede af statens og enkeltpersoners indsats på de nævnte felter og er, såvidt jeg ved, den første samlede skildring af alt dette set 
indefra og vurderet sagkyndigt af en mand, hvis livsgerning det har været at tage del i kreditforeningsarbejdet, domænevurderingen, Nordslesvigs elektrificering, jordfordelingen, Lånekassen for Sønderjylland, gældssaneringen under den store krise og meget andet. ( $P a ̊$ s. 94 efterlyser Refslund Poulsen Nordslesvigsk Kredilforenings forhandlingsprotokol, det er fantastisk og meget beklageligt, at den er forsvundet, den må kunne findes!)

Det vilde sprænge denne anmeldelses rammer at gå dybere ind på redeg $\phi$ relsen for de nævnte foretagender. Man imponeres af Refslund Poulsens arbejdskraft, hans sagkundskab og rolige omdømme. Også her mærker man mennesket bagved, arbejdet blev aldrig til »sager «.

Under skildringen af den store krise vedstår forfatteren sin sympati for L. S.-bevægelsen, men tager skarpt afstand fra de rabiate ledere. Man skal sikkert selv have haft »skoen på\& for at kunne forstå denne indstilling. Det gjorde bl. a. H. P. Hanssen ikke, og på dette ene punkt kritiserer forfatteren den ellers beundrede f $\emptyset$ rer og hans blad Hejmdal for manglende forståelse af krisens alvor.

Personerne, der omtales, får deres skudsmål, mange af dem i rammende småglimt. Det er naturligt, at $H$. P. Hanssen skildres udførligt. En anden af mellemkrigstidens hovedskikkelser, Martin Hammerich får vi et levende og detaljeret billede af. Det cr en glæde at læse om denne kloge og ædle personlighed, som fortjener en selvstændig skildring, der kan give ham og hans betydningsfulde, uselviske virke den centrale placering $i$ vor landsdels nyeste historie, der tilkommer ham.

Kapitlerne om nazismen og besættelsestiden giver vægtige bidrag til en vurdering af denne skelsættende periode, og også her træder forfatterens uafhængige og kritiske personlighed frem. Han vender sig lige stærkt mod visse tågede $h \emptyset j$ skolefolks forventninger om en folkelig fornyelse fra nazismen som mod nogle avisers, især Politikens servile skriverier i forvirrelsens sommer 1940. I modsætning til de fleste af sit slægtleds nordslesvigere forstår Refslund Poulsen modstandsbevægelsen og værdsætter dens indsats positivt især for vor folkemoral, som Scavenius-politikken tilf $\varnothing j e d e$ så stor skade.

Bogens sidste store afsnit om Sydslesvig er særdeles interessant og tankevækkende. For at skaffe sig et førstehånds kendskab til forholdene foretog forfatteren i 1935 en 8 dages studietur til Sydslesvig og tegner et vederhæftigt og veldokumenteret billede af det danske mindretals $\emptyset$ konomiske og folkelige vilkår på den tid. Ud fra sine forudsætninger måtte han reagere stærkt mod Sydslesvig-røret efter 1945 og dets statspolitiske målsæetning. 
Flan går afgjort imod talen om den danske folkegrund som løftestang for bevagelsen, ligesom han tager afstand fra den påståede parallel mellem røret i Sydslesvig og da $»$ Nordslesvig vågnede « hundrede år f $\varnothing \mathrm{r}$. Derimod stiller han sig ligesom Jakob Petersen absolut positivt til Sydslesvig-rejsningens folkeligt-kulturelle aspekter.

Til slut berøres arbejdet for at få Christmas Møller valgt i vor valgkreds ved folketingsvalget 1947. Det forekommer mig uforståeligt, at hans stillere ikke kunde se, at de gjorde Christmas Møller en bjørnetjeneste ved at være med til at tilføje ham dette sidste sviende nederlag.

Refslund Poulsen bidrager i forbigående til sin selvkarakteristik ved at sige, at han har manglet charme og en lykkelig hảnd, $o g$ et andet sted omtaler han sig selv som mere fordxkt end den typiske vestjyde. Hans bog støtter ikke denne opfattelse. Den er tiltrakkende ved sin livfuldhed og klogskab, ved sin åbenhed og åbenhjertighed.

Marten Refslund Poulsen har med afslutningen af denne erindringsbog indfriet den forpligtelse, som Jacob Appel stillede ham overfor ved Bovlund frimenigheds 50-årsdag i 1929, da han pålagde ham at skrive Bovlund-egnens og dens særprægede personligheders saga. Det er blevet et værk, der fylder ikke blot $i$ bredden, det går dybt, langt tilbage i tiden oğ har en vrimmel af levende træk fra oplevelser og om mennesker. Sagaen er fast komponeret. Man overvældes of te af enkelthederne, men de lange linjer, udsynet og overblikket går igennem det hele. Og forst og sidst er bogen holdt sammen af skribentens personlighed, der træder frem med sine markante træk, ikke så den dominerer, men giver det oplevede relief og liv. I mange måder traeder han for laseren frem som de Bovlund-folk havde ord for at være: Kantede og kritiske, selvbevidste og selvhjulpne bønder, fast forankrede $\mathbf{i}$ tilværelsens realiteter og samtidig med sans for oplysning og dyb respekt for åndelige værdier, åndeligt levende som de selv var jordnare og med en vid åndelig horisont.

A. Feilberg Jørgensen.

Personregistret har et par fejl i de anførte sidetal, og enkelte navneformer er ukorrekte. Det gælder L. S.-formanden, hvis navn skal skrives med ch, cndvidere forfatteren Age Meyer Benedictsen, og den professor Bentzen, der omtales pa s. 91 i forbindelse med Sonderjydsk Fond ma være prof. Viggo Bentzon, endelig mâ personregistrets: Oksen, Jens, Direktør, vare forvekslet med sin far, Peter Oksen. Slesvig-holstenismens lærefader må have sit navn med $w$, og der er faldet et $d$ ud i den tyske Organisation Todt's navn. 


\section{Bognyt}

Niels Friis: Marcussen \& Søn 1806-1956: Åbenrå 1956, 101 s.

+ tysk og engelsk resume.

Åbenrås ældste virksomhed, orgelfirmaet Marcussen \& S $\emptyset n$, har holdt 150 års jubilæum og har $\mathrm{i}$ den anledning formået den på orgelbyggeriets historie meget kyndige redaktør Niels Friis til at udarbejde et smukt festskrift. Der er ikke så lidt af et eventyr over grundlæggeren Jürgen Marcussens livsbane. Født i Snogbæk 1781 under små kår, der ikke tillod nogen systematisk uddannelse inden for det fag, han allerede fra barns ben havde besluttet sig til at virke $i$, arbejdede han sig ved flid og udholdenhed, bistáet af en intuitiv opfattelse af de fundamentale grundregler inden for orgelbyggeriet, frem til at indtage en førende plads inden for dette fag. Hans første orgel, et lille positiv på nogle få stemmer, var færdigt 1806 og er formentlig blevet opstillet på Tø̆der seminarium. I de første åringer bestod hans arbejde mest $i$ reparationer af landsdelens orgler, men senere, efter at han som medhjælper havde fået præstesønnen Andreas Reuter og virksomheden var flyttet til Åbenrå, byggedes store kirkeorgler, ikke blot i hertugdømmerne, men også i kongeriget. De to kompagnoner Marcussen og Reuter blev venner med de berømte organister og komponister C. E. F. Weyse og J. P. E. Hartmann, og næsten alle større orgelbygninger og -reparationer inden for helstatens område blev overladt Åbenrå-firmaet. Efter Reuters d $\emptyset \mathrm{d} 1847$ optoges sønnen Jürgen Andreas Marcussen som kompagnon. Han havde både hjemme og i udlandet fået en grundig uddannelse inden for sit fag, og under firmanavnet Marcussen \& S $\emptyset n$ vinder man nu indpas i Sverige, noget senere også i Finland. I fremmedherredømmets tid udførtes kun enkelte arbejder $\mathrm{i}$ kongeriget, og firmaets arbejdsområde kom helt overvejende til at ligge $i$ Tyskland. Først efter genforeningen har firmaet under ledels af Johannes L. og Sybrand Zachariassen igen kunnet indtage den førende stilling inden for dansk og nordisk orgelbygning, som det havde f $\varnothing \mathrm{r}$ 1864. Jubilæumsskriftet er især beregnet for fagfolk, men ogsa ikke-orgelkyndige vil med glæde kunne læse Niels Friis' skildring af udviklingen inden for det gamle firma, der på en så enestående smuk måde har formået at kaste glans over sønderjysk kunsthåndværk. Skriftet er forsynet med en mængde gode billeder af orgelfacader, og orgelkyndige vil gennem de talrige dispositioner kunne følge stiludvikling og mode indenfor orgelbyggeriet gennem halvandet hundrede år.

I'. K, I. 
Bjolderup sogns historie. Eget forlag 1951-56, 463 sider, ill.

Redaktion H. V. Gregersen og P. Kr. Iversen.

Når det for tiden påpeges, at det danske lokalhistoriske arbejde i grænselandet er blevet distanceret af det tyske, er det opmuntrende at bemærke det initiativ, der er taget i Bjolderup sogn, Aabenraa amt, med udarbejdelsen af en sognehistorie på 465 sider. Første halvbind fremkom i 1951 og andet i 1956.

Vanskeligheden ved at skrive sognehistorie ligger ikke $i$ at kunne samle stof nok, men $i$ at finde det rigtige og $i$ at koncentrere og afrunde dette på en fornuftig måde, således at det samtidig kan blive fængslende læsning. Afrundingen - og den vel sikkert uundgåelige kraftige beskæring - er lykkedes godt for de to redaktører, H. V. Gregersen og P. Kr. Iversen. Mens den første tegner sig for 10 af bogens 26 kapitler, må man nøjes med at spore Iversens kyndige hånd som râdgivende og inspirerende.

I. bind omhandler tiden indtil 1864. Klogeligt har man larlet en enkelt forfatter, Gregersen, behandle de ældre tider, herunder landstinget på Urnehoved, krigshistorien og de indviklede administrative forhold. En lille, men gedigen afhandling om Bjolderup kirke er skrevet af pastor Hans Madsen. Hans J. Bertelsen beskeftiger sig overvejende med erhvervsforhold, hans store afhandling om den $\varnothing$ konomiske udvikling er fængslende læsning, og han synes at være blevet en specialist på landbrugshistoriens område. Ialt har Bertelsen skrevet 8 afhandlinger, blandt hvilke også må fremhæves afsnittet „Fra verdenskrig til genforening $\alpha$, mens afsnittet om gårdenes historie fortrinsvis har interesse inden for sognets grænser. I Gregersens afhandling, ,Den nationale og folkelige udvikling * vækker oplysningen om, at af sognets c. 1275 indbyggere i 1875 var 138 danske undersåtter, deraf 101 direkte optanter, til eftertanke.

Jakob Holdt tager sig af skolevæenet, de sociale forhold og hverdag og fest i gamle dage. Lærernes aflónning har til tider været så ringe, at det i 1700 tallet er forekommet, at indtægten har måttet forbedres ved smugkrovirksomhed.

Jens Holdt fremhæver i 2. bind i sit afsnit om de kirkehistoriske forhold med fin forståelse af problemet det tragiske i den dobbeltrolle, de fleste præstemænd i preussertiden kom til at spille, når de skulle stå som den kristne menigheds og tillige den preussiske stats repræsentanter $i$ et overvejende dansk indstillet grænseland. Holdts varmfølte skildring af sognets betydeligste nationale fører i nyere tid, Rasmus Clausen, Smedager, efter Karsten Thomsens død i 1889 den tids betydeligste folkedigter $i$ Nordslesvig, er bragl udf $\emptyset$ rligere $i$ Sønderjyske årb $\emptyset$ ger 1956 (II. halvbind).

Man må i høj grad anerkende det flittige og grundige arbejde, som ligger til grund for Bjolderup sogns historie og for den måde, pa 
hvilket det store stof er sammenfattet og anbragt i den naturlige sammenhæng, uden at bogen skæmmes af gentagelser, en ellers ofte forekommende mangel ved gruppearbejder.

Alt i alt har Bjolderup sogn, ja hele Sønderjylland, grund til at føle stolthed og glæde ved dette solide og værdifulde stykke hjemstavnshistorie.

Chr. St.

Bjørn Svensson: Sparekassen for Haderslev Byes Omegn. 100 Aar i Landsdelens Tjeneste. Haderslev 1956. 72 s., ill.

Da Sparekassen for Haderslev Byes Omegn i 1931 kunne fejre 75års jubilæum, lod styrelsen daværende folketingsmand, redaktør $A$. Svensson udarbejde et udførligt værk om sparekassens historie, og da sønnen, redaktør, cand. polit. Bjørn Svensson derfor i 1956 i anledning af 100-års jubilæet fik overdraget at skrive et nyt festskrift, har han ganske naturligt ladet sparekassens historie træde noget i baggrunden. Forfatteren giver i stedet indledende en skildring af de $\phi \mathrm{ko}$ nomiske og nationale forhold $i$ tiden $f \emptyset r$ oprettelsen, men også $i$ de følgende afsnit yder han i tilknytning til sine rids over sparekassens virke bidrag til den nationale og økonomiske historie i by og egn.

Bjørn Svensson er den erfarne journalist, hans skildring af tiden er derfor ikke alene let læselig, men også fængslende, og samtidig har han forstået fra gamle aviser og andre kilder at fremdrage mangt et småtræk, som øger vor viden om Haderslev by og egn navnlig $i$ midten af 1800-årene.

Den lille bog, der er en værdifuld tilvækst til den efterhånden righoldige litteratur om Haderslev by og amt, er overordentlig smukt illustreret dels med udmærkede portrætter af sparekassens ledende mænd og dels med en lang række pyntelige tegninger fra by og egn af Svend Erik Ihle.

o. C.

Olav Christensen: Haderslev bys håndværk. Festskrift udsendt i anledning af Haderslev Håndværkerforenings 100-årsdag den 6. januar 1957, Haderslev 1957, 109 s.

Olav Christensen er en såre flittig og dygtig mand. Trods mange andre opgaver har han igen fået tid til at udarbejde et jubilæumsskrift og ligesom $i$ andre tilfælde har han ikke villet nøjes med udelukkende at skildre den jubilerende forenings, i dette tilfalde Haderslev Håndværkerforenings historie, men han har $i$ indledende kapitler berettet om håndværkets kår $\mathrm{i}$ tiden forud for 1857. Der berettes om hândværkerlavene i nedgangs- og opgangstider, om lavsskråerne og deres indhold, om medlemmernes pligter og rettigheder, om konkurrencen med mestrene på Slotsgrunden, med frimestre, 
landhåndværkere og særligt udførligt om stridighederne med Christiansfeld i slutningen af 18. århundrede. Lavstvangen ophævedes her i Sønderjylland først 1867, men allerede 10 år forinden var den haderslevske håndværkerforening blevet oprettet. Foreningen fik ret snart en betydelig tilgang af medlemmer og kom til på en stille og værdig måde at præge byens faglige, sociale og kulturelle liv. Ved udstillinger har man søgt udadtil at vise det haderslevske håndværks formåen og kunnen. Foreningen var fra første færd orienteret i dansknational retning. I fremmedherredømmets tid så man sig dog nødsaget til af forsigtighedsgrunde at fjerne et lille Dannebrog fra foreningsbanneret, men forbindelsen med kongerigske fagfæller holdtes vedlige ved gensidige bes $\varnothing$ g. En særlig omtale er blevet grundlæggeren af det svenske socialdemokrati, August Palm, til del. Han opholdt sig $i$ byen $i$ årene 1871-77 som skræddersvend, men blev på grund af sin socialistiske virksomhed først excluderet af håndværkerforeningen og et årstid efter udvist af Tyskland. I et slutningskapitel fortælles om Teknisk Skole, der begyndte sin virksomhed 1920, og som fik sin egen bygning 1923. Bogen er forsynet med et godt billedmateriale, med kildehenvisninger og et personregister.

P. K. I.

Olav Christensen: Haderslev Skydeselskab af 1857, Haderslev 1957, 77 s.

I dette rigt illustrerede lille skrift har forfatteren givet en let læselig skildring af foreningens omskiftelige historie og har herved ydet et nyt, værdifuldt bidrag til belysning af det danske foreningsliv $i$ Haderslev. Der er i bogen forskellige oplysninger af mere almen interesse. Således nævnes, at tiltrods for at skydeselskabet var en dansk national forening, taltes der dog i årene for 1864 ret fremtrædende slesvig-holstenere eller andre tysksindede blandt selskabets medlemmer. I denne forbindelse nævnes, at under Frederik VII's bes $\phi$ g i Haderslev 1863 var flere hjemmetyskere m $\phi d t$ op for at hylde kongen, og forfatteren er tilbøjelig til at give Edv. Lembcke, der på den tid var lærer ved latinskolen, ret $i$, at der var ved at ske skred $i$ de slesvig-holstenske rækker, og at adskillelsen fra moderlandet $i$ 1864 satte en stopper for denne udvikling. Men selv efter 1864 forblev tysksindede medlemmer $\mathrm{i}$ foreningen, og særdeles bemærkelsesværdigt er det, at 1865 optoges selve borgmesteren, den tysksindede Peter Brodersen Hansen, som medlem. Selskabet synes i dets første år til en vis grad at have stået som formidler mellem dansk og tysk. Senere, fra 1870 'erne, udsættes foreningen for chikanerier fra tyske myndigheder, medlemstilgangen svigter, og i 1890'erne må virksomheden indstilles for først at kunne genoptages 1913.

P. K. I. 
Olav Christensen: Frimureriet i Haderslev. Haderslev 1957. 90 s.

Ifølge sagens natur er denne bog, udgivet $i$ anledning af Haderslev frimurerloges 75 års jubilæum, kun bestemt for en snæver læserkreds. Når den alligevel omtales her, er det ikke alene på grund af den flid og omhu, Olav Christensen har anvendt, og som $g \varnothing r$, at den opfylder betingelserne for at kunne kaldes en værdifuld historisk redeg $\emptyset$ relse, f. eks. er de ret få tilgængelige kilder blevet grundigt unders $\varnothing \mathrm{gt}$ og alle væsentlige ting kommet med. Men der belyses desuden her sider af kulturhistoriske og nationale problemer i grænselandet, der ikke er uvæsentlige, når et historisk helhedsbillede skal søges trukket op.

Man erfarer, hvorledes en loge omkring 1850 på grund af slesvigholstensk infiltration ikke kunne anerkendes. Chr. Flor, der ikke selv var frimurer, giver sit besyv med også her, og der fortælles, at Laurids Skau blev optaget $i$ en anden frimurerloge. Først i 1882 anerkendtes logen $\gg$ Josva af den rigstyske sammenslutning, dog med kun få dansksindede medlemmer, mens de фvrige derboende danske frimurere dog bes $\varnothing$ gte logen og $i$ det hele taget havde nær kontakt med den. Lederen, landinspekt $\emptyset r$ Ths. Meyer ( $d \phi d$ 1902), skildres med sympatiske farver. Efter overenskomst mellem de danske og de tyske landsorganisationer indtrådte logen i 1921 i den danske landssammenslutning, men med tysk sprog ved nogle af sammenkomsterne.

Det fremgår af bogen, at forholdet mellem dansk- og tysksindede både før og efter genforeningen har været godt, og man læser mellem linierne, hvilken indflydelse institutionen har haft $\mathrm{i}$ kritiske tider med hensyn til at mildne nationale modsætninger. Men i 1926 f $\varnothing$ rte en af logens ledende mænd, advokat G. Vogelgesang, den skærpelse af nationalitetskampen, som da fandt sted, og som i særlig grad er knyttet til hans navn, ind på logens enemærker. Det medf $ø$ rte, at han og langt de fleste tysksindede trådte ud og dannede en egen tysk loge, hvilket forresten kom til at svie hårdt til dem, da nazisternes noksom bekendte holdning over for frimurerne resulterede $i$ deres isolation både fra tysk og dansk side.

En særdeles interessant og fængslende bog, hvor ydermere det nydelige udstyr og de gode illustrationer må fremhæves.

Chr. St.

K. Edvard Larsen: Gennem hundrede år. Enigheden i Sønderborg, Sønderborg 1957, 34 upag. s.

I anledning af 100-årsdagen for den selskabelige forening •Enigheden i S $\emptyset$ nderborg har den ved sin formand, redakt $\varnothing \mathbf{r}$ K. Edv. Larsen udsendt et smukt lille jubilæumsskrift, hvori der ikke blot fortælles om selve foreningens historie, men tillige som baggrund for skildringen berettes adskillige interessante enkeltheder om udviklingen i 
Sønderborg gennem det forløbne sekel, især naturligvis på det nationalpolitiske område. Ledende personligheder indenfor foreningen, der sammen med den ligeledes i 1857 stiftede Borgerforeningen. blev de danskes samlingssted i Sønderborg, har gennem årene været advokat J. C. Pingel, købmand A. V. Karberg, direkt $\varnothing \mathbf{r}$ H. G. Jacobsen, driftsbestyrer G. Jespersen og redaktør K. Edv. Larsen. Gennem sine jubilæumsskrifter har sidstnævnte ydet betydelige bidrag til belysning af Sønderborgs historie i fremmedherred $\varnothing$ mmets tid.

P.K.I.

Landet bag digerne. Hjemstarnsbog for Tønder amt og by.

Tonder 1956, $148+44$ s., ill.

-Landet bag digerne er udsendt af Tønder kommune og, som borgmester J. Paulsen fremhæver $i$ forordet, fơrst og fremmest tænkt som hjemstavnsbog for skolerne, idet den dog ikke alene skulle give skoleungdommen i by og på land et nærmere kendskab til hjemegnens historie, men også være en hjælp for ungdommen i Tønders nordiske venskabsbyer til at uddybe interessen for det nordiske samarbejde.

Bogen er redigeret af fhv. amtslæge, dr. med. H. Lausten-Thomsen, men af forordet fremgår det, at redaktionen f $\phi \mathrm{rst}$ er overdraget ham på et ret sent tidspunkt. Selv om det derfor ikke helt har kunnet undgås, at der har indsneget sig enkelte gentagelser, er det dog lykkedes og med afgjort held at samarbejde de enkelte bidrag til en helhed, som har føjet endnu en værdifuld bog til den lange række, der foreligger om Tønder-egnen.

Lausten-Thomsen fortæller indledende om landets tilblivelse og fører læseren på en rundtur $i$ dette lille, men $i$ naturmæssig henseende så interessante landområde. Oldtiden er behandlet af Kr. Kristensen og afrundes $i$ en artikel af Knud Fan $\varnothing$ om landsdelens mærkeligste oldtidsfund guldhornene fra Gallehus. Den nyere tids historie indledes af en artikel af Erling Brahm om landets urolige nabo, Vesterhavet, der både $i$ storm og stille har betydet så meget for vestboens liv og virke. Sigurd Schoubye fø̆rer os på en interessant vandring gennem det gamle Tønder og fortæller om det gamle Tønderhus og gader og huse, medens Werner Christiansen $i$ to artikler om bondekår og om adel og storgårde giver en skildring af landbrugsforholdene, $\operatorname{og}$ N. J. Thiim fortæller om handel og håndværk, for hvilken første studene og kniplingerne havde så stor betydning. Det åndelige liv skildres $\mathrm{i}$ to artikler, kirker og klostre, der også rummer nogen kunsthistorie, og åndelige rørelser af Kaj Sieverts og LaustenThomsen, medens Werner Christiansen af historiens billedbog navnlig skildrer krigshistorien. Den nationale udvikling og den nyeste tids historie fra omkring 1840 behandles af Knud Fan $\emptyset$, der har taget sig 
af tiden omkring midten af 1800-årene, og af Lausten-Thomsen, der $i$ to artikler skildrer tiden under fremmedherredømmet og efter genforeningen, og endelig giver Lausten-Thomsen en række eksempler på gamle sagn og den overtro, vore forfædre var besjælede af.

Bogen afrundes med tre digte af A. Egeberg Jensen, Hans Storm og Hansigne Lorenzen om vestkystens særprægede landskah og natur og afsluttes med udmærkede navne- og emneregistre samt en litteraturfortegnelse, der rummer de vigtigste trykte kilder til byens og amtets historie og g $\phi \mathbf{r}$ det muligt for den læser, der bliver indfanget af læsningen og derfor måtte ønske yderligere oplysninger, nemt og smertefrit at finde frem til den let tilgængelige litteratur, som findes om alle de forhold, bogen omhandler.

Bogen er forsynet med et rigt og skønsomt udvalg af billeder, der på fortrinlig måde illustrerer det store emne både $\mathrm{i}$ historisk, topografisk og kulturhistorisk henseende.

Selv om forfatterne indenfor de afstukne rammer har givet gode oversigter over de enkelte afsnit af byens og amtets udvikling, vil der $i$ et sådant værk altid kunne påpeges mangler, det synes $\mathrm{f}$. eks. her, at skolen har fået en noget stedmoderlig behandling; men som helhed må og skal det siges, at opgaven er løst godt, at man her virkelig har fået en bog, der på en oversigtlig og anskuelig måde skildrer den snævrere hjemstavn, og som på grund af sin ret beskedne størrelse sikkert vil blive læst $i$ vide kredse.

Olav Christensen.

G. Lind: Lind-slægten fra Lindgård* gennem fem hundrede år samt slagten Lunde (Flemløse-Skartved), Brems (SkærbakHersle -Brøndsted), Lomholt (Vejlby-Store Velling). - Min fædrene og min mødrene slægts historie syd og nord for Kolding fjord I - II, Kolding 1956, 218 s. + 347 s. + blanke sider til supplerende oplysninger.

G. Lind: Om smadderkatte, jernkфer og langovrede træsko.

Bøndernes livsvilkår i det gamle Tyrstrup herred 1526-1864, Kolding 1956, $127 \mathrm{~s}$.

Det er en imponerende indsats af tid og penge, der er anvendt ved udgivelsen af denne slægtshistorie, som må henregnes blandt de største danske, i hvert fald rent kvantitativt set. $\mathrm{Og}$ det er vel tvivlsomt, om der overhovedet findes en større dansk slægtshistorie, der som denne i det væsentlige omhandler bondeslægter. Det er slægter omkring Kolding fjord, der her er gjort til genstand for dybtgående undersøgelser, men omtalen her skal dog begrænses til slægterne fra Tyrstrup herred. Lind-slægten kan føres tilbage til Fjelstrup, hvor den på reformationstiden havde et kirketoftebol. I midten af det 18. ârhundrede omplan- 
tedes den til Lindgård i Dalby, og herfra stammer slægtsnavnet. Der gives udførlige oplysninger om de to sønderjyske gårdes skæbne gennem vekslende tider, om drift, besætning, agerbrug, de kvindelige sysler og $i$ det hele taget om livet, som det levedes $i$ arbejde, $i$ fest og $i$ sorg, for så vidt kildematerialet har tilladt det. De to store bind får derved også betydning og værdi uden for den snævre familiekreds. Der kastes strejflys ind over Tyrstrup herreds politiske og $\varnothing$ konomiske historie og almindelige kulturelle udvikling. Forfatterens farfader, Johs. H. Lind (d. 1860) var nabo til den kendte slesvig-holstenske politiker Andreas Petersen, Dalbygård. Han er ikke blot foregangsmand på det landbrugstekniske område ved på et tidligt tidspunkt at lade udføre omfattende dræningsarbejder og ved at lade den tunge hjulplov afløses af svingploven, men stærkt påvirket i grundtvigsk retning var han en af initiativtagerne til oprettelsen af en bondehøjskole i Sønderjylland. Sønnen Hans var elev på Rødding højskole det første år, Flor var forstander der, og Johs. H. Lind var med blandt de 100 mænd, der 1843 skaffede midlerne til $k \emptyset b$ af Skamlingsbanken. Det vilde føre for vidt at komme narmere ind på de mange interessante enkeltheder, forfatteren har fremdraget af tingbøger, skyld- og panteprotokoller, jordeb $\emptyset$ ger, beskrivelser og familiepapirer. Blot vil der være grund til at nævne, at i de afsnit, hvor han holder sig til belysningen af de enkelte slægtsgrenes historie, er skildringen absolut bedst. Hvor han som i den omfangsrige indledning s $\varnothing$ ger at generalisere, er der adskillige usikre og uklare punkter. Man møder $\mathrm{i}$ indledningen, der iøvrigt er udsendt som en selvstændig bog under den mærkelige titel: Om smadderkatte, jernkøer og langovrede træsko, ofte en ejendommelig sammenblanding af kongerigske og slesvigske forhold. Som et af de mest grelle eksempler kan anføres, at forf. s. 104 uden at blinke giver læseren det indtryk, at hartkornsmatriklen også havde gyldighed i Sønderjylland. I et par ord kan indledningen vel karakteriseres som ret tilfældig og springende, men ikke uden interessante enkeltheder. Der er ingen kildehenvisninger, og det er derfor vanskeligt at kontrollere de meddelte oplysninger, men det kan dog ses, at der $\mathrm{i}$ indledningen er mange og til dels lange næsten ordrette citater med og uden citationstegn fra trykte bøger. Der er i værket mange billeder af slægtens medlemmer og af indbo, som endnu har sin plads på den gamle slægtsgård Lindgård.

P.K.I.

Centraladministrationens afleveringer til Rigsarkivet 1921-45. Udgivet af Rigsarkivet.

Ved C. Rise Hansen. Ejnar Munksgaard. 1956. 53 sider.

Denne fortegnelse over centraladministrationens afleveringer til Rigsarkivet er en fortsættelse af den fortegnelse, der rummes i $\gg$ Med- 
delelser fra det danske Rigsarkiv I 1906-18«, side 99-103. Den samlede aflevering $i$ de 25 år fra 1921-45 omfatter ikke mindre end 27.938 protokoller og 81.390 aktpakker, svarende til ca. 10.700 hyldemeter, en oplysning som vel kan give en forståelse for de pladsproblemer, så at sige samtlige arkiver kæmper med. Den lille bog er især beregnet for centraladministrationens mange kontorer, men vil derudover kunne tjene fremtidens historieforskning. Af særlig interesse for »Sønderjyske årbøger«s læsere vil det være, at arkivet fra Det midlertidige ministerium for sønderjyske anliggender er blandt det af Statsministeriet afleverede. Dette arkiv omfatter ialt 58 bd. og 107 pakker, herunder eksempelvis sagerne vedrørende kringsfanger og afstemningen. Under Landbrugsministeriets afleveringer finder man sager vedrørende udstykning af domænejord i Sønderjylland, under Undervisningsministeriet en aflevering fra det kgl. preussiske provinskollegium i Slesvig: Akter vedr. den tidligere overrealskole i Sønderborg.

K.F.

I Rigsarkivets skriftserier er udkommet femte bind af wKronens skøder*, omfattende tiden 1731-1765, ved S. Nygaard, 1955, og i Kancelliets brevbøger bindet 1642-1643, 1957. Udgivelsen af Kancelliets brevb $\emptyset g e r$ er efter arkivar Emil Marquardts d $\emptyset$ d overdraget arkivar Gunnar Olsen. I dette bind af Kronens sk $\emptyset$ der finder man eksempelvis kildestof vedr. Notmark kirke og mølleriet ved Trøjborg. I Kancelliets brevbøger finder man især værdifuldt stof vedr. enklavesognene. Der kan måske være grund til endnı en gang at fremhæve, at navneregistrene $g \emptyset r$ det til en let sag for den lokalhistorisk interesserede at se, om der i den pågældende udgivelse er stof af særlig værdi for ham.

K.F.

Nikolaj Andersen: Sønderjydske digte og fortællinger.

Udgivet af Sprogforeningen. Dy-Po bogforlag 1956. 228 sider.

Det er en fortjenstfuld indsats, Sprogforeningen har $\phi$ vet, gennem den nye og udførligere udgave af Nikolaj Andersens digte og fortællinger. Morten Kamphøvener tegner $i$ sit forord et smukt billede af denne mand, der med et matematisk studium bag sig, ønskede at hellige sig sprogforskningen, men blev hindret deri af stærk bundethed af praktiske gøremål i nationalitetskampen. Den nye udgave vil gøre sit til, at den digtning, der blev hans særlige område, den rimede humoristisk, ofte anekdotiske fortælling, vil blive husket. Man træffer stadig ældre sønderjyder, der kan store dele af Nikolaj Andersens forfatterskab udenad. Ofte møder man således $i$ folkemunde de fortællinger, der bag et ydre lag tysk fernis afslører den danske oprindelighed. 
Digtene og fortællingerne i sig selv fængsler endnu læserne - og så giver de et værdifuldt indblik i sider af den $\emptyset$ stslesvigske befolknings tankegang, dens oplevelser og dagligliv i et par tiår af fremmedherredømmets tid. Samtidig er så Felstedmålet, som Nikolaj Andersen selv kalder det, men, som udgiveren med rette gør opmærksom på, med små afvigelser tales over hele Sundeved og på Broagerland, atter blevet fæstnet til papiret. De til fortællingerne og digtene oprindelig knyttede illustrationer af Poul Steffensen, Tom Petersen, Hans Tegner og Alfred Larsen illustrerer ogsá den nye udgave.

K.F.

Kongens Fodregiments historie gennem 300 år.

Tønder 1957. 143 sider, ill.

Kongens Fodregiment, indtil 1950 2. Bataillon, fejrede sin 300 årsdag i dette forår ved udsendelsen af denne bog. Dens første 98 sider er et optryk af krigshistorikeren, kaptajn K. C. Rockstrohs : Fortællinger af 2. Bataillons Historie $1657-1907 \ll$, og derefter bringes oberst N. F. Ravns skildring: »Træk af Kongens Fodregiments historie 1907-1957\&. Bogen beretter om styrkens tilværelse $\mathrm{i}$ krig og fred gennem de 300 år; med interesse læser man således om dens stilling den 9. april 1940. Bogen vil have særlig interesse ved det billede, den tegner af garnisonens stilling i den udprægede grænseby Tønder. Man får et indtryk af, hvordan garnisonen i nationalt rolige tider har haft det bedste forhold også til borgere, der tilhørte mindretallet. Men også de nationalt urolige tider genspejles, således april 1933, da dragonerne, der i 1932 var blevet forlagt, for en tid kaldes tilbage til Tønder for at forhindre, at de af »påskestormen« opfanatiserede S.A.-formationer sydfra skal overskride grænsen. N. F. Ravn har ved sin skildring ydet et solidt bidrag til den lokalhistoriske litteratur om Tønder.

K.F.

Afhandlinger tilegnede arkivmanden og historikeren rigsarkivar, dr. phil. Axel Linvald af nordiske fagfæller på halvfjerdsårsdagen 28. januar 1956.

Under redaktion af Johan Hvidtfeldt og Harald Jørgensen.

København. Rosenkilde og Bagger 1956. 342 sider.

Dette festskrift til den nu afgåede rigsarkivar, dr. phil Axel Linvald, runmer 26 afhandlinger med vidt forskellige emner fra tiden omkr. 1500 til besættelsen. Som naturligt er med henblik på rigsarkivar Linvalds fremtrædende placering i sønderjysk historieforskning og historieskrivning tager en del af afhandlingerne deres emne fra sønderjysk historie. Da disse afhandlinger vil have stor interesse for læserne af 
Sønderjyske årbøger, skal de anf $\varnothing$ res her. Troels Fink bringer sin vurdering af »De dansk-tyske forbindelser gennem de sidste 150 år«, et foredrag holdt ved det tysk-nordiske stævne i Lübeck i 1954. Frode Gribsvad har en afhandling $\gg$ Hvad fortæller retsprotokollerne om retssproget i Nordslesvig? \& - et bidrag, der underbygger det alm. billede af forholdene på retssprogets område og slutter i en unders $\emptyset$ gelse af, hvordan sprogreskriptet af 1840 blev gennemført $i$ de enkelte dele af Nordslesvig. Johan Hvidtfeldt giver i sin redeg $\varnothing$ relse $\gg$ Peter Kragh og Alexander Thomsen. Det tyske mindretal i Nordslesvig og diskussionerne om befolkningspolitik interessante oplysninger om de modstridende synspunkter, der inden for tysk udforskning af mindretallets befolkningsmæssige placering, set på baggrund af grænserevisionistiske фnsker, i begyndelsen af 1940erne kunne g $\phi r e$ sig gældende. Peter Kr. Iversen har fortsat sit arbejde med Wulffslægten med en afhandling om Jens Wulffs broder $\gg$ Hans Andreas Wulff. En jysk landmand og politiker af slesvigsk rod\%. Afhandlingen er udførligere omtalt i Sønderjysk månedsskrift 1956, 3. - Harald J $\emptyset$ rgensen har underkastet »Åbenråresolutionens tilblivelse en kildekritisk undersøgelse, som det vil være naturligt for læserne af denne årbog at læse i forlængelse af den her bragte redeg $\varnothing$ relse for oktoberadressen. Endelig skriver Erik Kroman om $\gg$ De sønderjyske fyrstearkiver i Rigsarkivet«, en redeg $\emptyset$ relse for fællesarkivet, gottorparkivet og de s $\phi n-$ derborgske hertugers arkiver. Kroman slutter sin afhandling med at berette om afleveringen af arkivalier til Tyskland og hilser med glæde, at de afleverede arkivalier nu er anbragt på Gottorp, hvorved de er let tilgængelige for den historiske forskning i Nordslevig.

K.F.

\section{Dansk idræt i grænselandet.}

Sønderjysk Idrætsforening 1903-1953.

Under redaktion af Chr. Petersen og Peter Kr. Iversen.

Haderslev 1957. 306 sider, ill.

Inden for S $\varnothing$ nderjysk Idrætsforening er der $\emptyset j e n s y n l i g$ tradition for, at dens jubilæumsskrifter udkommer nogle år efter jubilæet. Adler Lunds bog, der skildrede 25 året 1903-1928, udkom i 1932, og nu foreligger bogen udgivet $i$ anledning af 50 års jubilæet under redaktion af redaktionssekretær Chr. Petersen og arkivar Peter Kr. Iversen. Det er blevet en bog, der går grundigt til værks - ofte fảr kilderne selv lov at tale - og en bog, der giver et stærkt og nuanceret billede af idrættens udvikling i grænselandet fra dens f $\varnothing$ rste famlende begyndelse til de faste rammer, hvorunder den nu udøves. Bogen er blevet til idrættens historie, idet man også har medtaget den idræt, der udøves uden for 
Sø̆nderjysk Idrætsforenings rammer. Man får et stærkt indtryk af idrættens placering $i$ den bredere nationale kamp, og igennem den form, skildringen har faet, bliver den et værdifuldt bidrag til den almindelige nationalitetskamps historie. Der er et langt spring fra dengang, gymnastikken måtte drives i storstuer og lader, til nutidens gymrastiske ud $\emptyset$ velse $\mathrm{i}$ bekvemme og velopvarmede gymnastiksale.

Chr. Petersen skriver på grundlag af foreningens forhandlingsprotokoller om tiden til 1920, da foreningen bar navnet $\gg$ Nordslesvigsk Fællesidrætsforening*, og $i$ et tillæg hertil behandler han Nordslesvigsk Hjulriderlag «. Der fortælles udf $\phi r l i g t$ om den udvikling inden for arbejdet, der fandt sted trods myndighedernes forfølgelse, og om en række af de ledende mænd i arbejdet, oftest mænd, der også på anden måde er placeret $i$ denne tids Sønderjyllands historie. - Foreningens formand siden 1949, stadsskoleinspekt $\varnothing r$ S. P. Hansen, skriver om foreningens udvikling i tiden 1920-1953; medlemstallet i 1953 udgjorde 23.117; også de interne stridigheder, der har stået på inden for perioden, får deres plads. Iøvrigt tegnes der et smukt billede af foreningens formand gennem de forste 29 år efter genforeningen, gårdejer Johs. Juhl, Branderup.

Bogens resterende afsnit er helliget de enkelte grene af foreningens arbejde og skrevet af særligt sagkyndige, der har stået nært tilknyttet s $\emptyset$ nderjysk idræt. Idrætsinspekt $\phi \mathbf{r}$ Braae skriver om gymnastikken, lærer A. B. Mikkelsen om boldspillet, lærer C. J. Laursen og seminarielærer Folmer Lund om den frie idræt på landet og i byerne. Folkedansen har sit særlige afsnit skrevet af lærer Sven Gammelgaard, skyttesagen og skytterne behandles af lærer Vilh. Jørgensen og Bertel Michaelsen. Om gymnastik, idræt og ungdomsarbejde i Sydslesvig skriver Niels Kjems og Franz Wingender, idet Sønderjysk Idrætsforening i overensstemmelse med sit navn i 1932 udvidede sit arbejde til Sydslesvig. Lektor Magelund har givet en skildring af svømningens kår i Sønderjylland, Peter $\mathrm{Kr}$. Iversen skriver om idrætsarbejdet uden for Sqnderjysk Idratsforening, herunder rosporten; Müller-Kristiansen beretter om idræetshøjskolen i Sønderborg, og endelig fortæller Chr. Petersen om landsfester og opvisninger, således om det store stævne den 12. maj 1933 i Tønder, hvor 15.000 mennesker gav svar på udfordringen sydfra. Bogen sluttes med en række biografier og en medlemsstatistik. Det havde lettet den senere benyttelse af bogen, om der havde været navneregister, men фkonomien har vel sat en grænse for bogens omfang. Bogen, der så afgjort har interesse også ud over de egentlige idrætsudøveres kreds, fås ikke i bogladen, men gennem styrelsens medlemmer og ekspederes af overlærer Jepsen, Engvej 2, Aabenraa. Bogens pris er $10 \mathrm{kr}$. uindb., $14 \mathrm{kr}$. indb.

K.F. 
Jacob Kronika: Lys i vinduet. Slesvigske dagbogsblade

fra Berlin 1933-39.

Det danske Forlag. 1957. 206 sider.

Fra første sætning mærker man, at det er en fremragende journalist, der har skrevet denne bog. Og hvilket stof - fuldt af spænding! Man f $\emptyset$ lger forfatteren ind og ud af de nazistiske regeringskontorers ellers sả lukkede døre; man træffer sammen med ham nazistiske koryfæer som Hitler, Himmler og Rosenberg og har det indtryk, at man kender dem, når man har mødt dem i følge med Kronika. Man forstår mere end før af nazismen i teori og praksis, når man har læst Kronikas bog. Det var som Flensborg Avis' berlinredaktør og som akkrediteret talsmand for det danske mindretal, Kronika opholdt sig i Berlin i disse år. Hans bog, bygget op over dagbogsblade, kaster da også kraftigt lys ind over mindretallets vilkår under nazismen. De velkendte problemer, fors $\emptyset \mathrm{g}$ på at tvinge børn ud af danske skoler, arvegårdslovgivningen udført således, at kun tyske kunne få jord, de unges forhold under militartjeneste og $\mathrm{i}$ arbejdslejre, behandles. Kampen om pressen får et særligt afsnit - begyndende med forbudet mod $\gg$ Der Schleswiger 1937 og den f $\varnothing$ rste »Verwarnung tegner et meget smukt billede. I andre afsnit hører man om de tyske modstandere i grænsekampen, mænd som Lohse, Sieverts og Ernst Schrøder.

Nazismens stilling til nordgrænsen og kravene om revision belyses indgående. I disse afsnit er der adskillige hidtil ukendte synspunkter og oplysninger. Med interesse vil også biografierne af Fritz Clausen og Jens Møller, Kronikas gamle skolekammerater fra Flensborg, blive læst. Man fornemmer, at Kronika her har en sikker vurdering af, hvad der førte Fritz Clausen til den danske nazisme og Jens Møller over i den tyske lejr. Jacob Kronika, der har taget Jens Jessens ord om $\gg$ Lys i vinduet\& som titel til sin bog, har som grænsebo i disse biografier som iøvrigt i sin bog - også i afsnittet om den tidligere duborgelev, der fører direkte frem til brugen af ordene - vist fin forståelse for, hvordan ydre omstændigheder i samspil med individuelle anlæg, kan være bestemmende for den enkeltes nationale stillingtagen.

Den, der har oplevet 1930erne i al deres spænding, finder klarhed over mangt og meget ved læsning af Kronikas bog - også over mere end denne korte omtale kan antyde. Bogen er journalistisk udformet, uden klar angivelse af, hvor dagbogsbladene ophører, går forfatteren videre $\mathrm{i}$ fortælling og ræsonnement. Derfor må selve dagbogsbladene sikres $\mathrm{i}$ deres oprindelige form for eftertidens historikere.

K.F. 


\section{Noter og nyt}

\section{Svend Anker Hanssen,}

\section{1.1893 - 18. 10.1956 .}

Svend Anker Hanssen var søn af Chresten Hanssen på N $\varnothing$ rrem $\varnothing l l e$ og hans hustru Dorthea. Ved hans jordefærd udtalte gårdejer Jørgen Lyck fra V. Sottrup, at hans og hans fars navne står med guldbogstaver $\mathbf{i}$ 》Den almindelige Brandforsikring for Landbygninger«s annaler.

Om Dorthea fra Nørremølle har

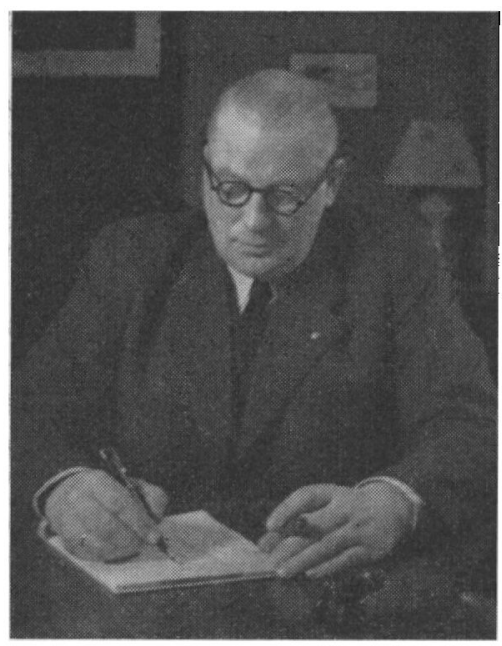
kammerherreinde Refslund Thomsen skrevet en yndig lille bog. Også den, der ikke har kendt hjemmet, finder let forståelse af de gode forhold, som Svend Anker er vokset op i. Endda skildres hjemmet kanske aller smukkest i nogle få linjer, Erik Skram i 1888 sluttede sin lille bog $\gg$ Hinsides grænsen med: »Den ene fædrelandssang blev sunget efter den anden. Aftenen var stille, det blev svalt, solen var forlængst gået ned, stemmerne lød hårdt $i$ den klare luft. Drengen stod og lyttede til. Det var Sønderjyllands historie i de kommende lange år, jeg så; barnebarnet, der nemmer, hvad der bliver sunget og talt i dets fødestavns luft $\ll$. Det

var H. P. Hanssens og Chresten Hanssens, som det var Svend Ankers, og dette hjems tone lả alle vegne bag de 3 frænders arbejde, Nørremølles gode danske tone. Svend Anker var af dem, der altid bar hjemmet med sig, hans og fru Dagny, f. Laursens gode hjem. sHan var altid med til at hjælpe opad, stod der som overskrift over en mindeartikel ved hans død. s Når Svend kom, blev der altid højere til loftet blev der sagt ved en mindeh $\phi$ jtid efter hans begravelse. Forholdsvis sent kom han $\mathrm{i}$ forgrunden $\mathrm{i}$ vort nationale arbejde, som formand for sognets Danske Samfund og for forsamlingsgården Sundeved. 1949 blev han medlem af Sønderborg amtsråd, i mange år var han fra 1933 direkt $\varnothing r$ for Den almindelige Brandforsikring for Landbygninger med kontor i Sønderborg. Frejdig i sin fremtræden, festlig, 
når han stod som leder af et møde, af skikkelse en høvding, men jævn $i$ sin optræden, en fremstående fortæller, stærk $i$ sin overbevisning stod Svend Anker også i de 5 tunge år. Han valgtes i 1947 som Hans Alexandersens efterf $\varnothing$ Iger $i$ styrelsen for Historisk Samfund for Sønderjylland og tog ivrigt del i dens drøftelser. Når han ikke var til stede, savnedes han. Der var altid højtid om Svend Anker Hanssen, og han vil længe blive savnet $i$ Historisk Samfund og mange andre steder.

H. Lausten-Thomsen.

\section{Overarkivar, dr. phil. Holger Hjelholt -70 år.}

Den 12. november 1957 fyldte overarkivar i Rigsarkivet, dr. phil. Holger Hjelholt 70 år. Han kom som ung ind i Rigsarkivet, hvor han har virket, indtil han i 1956 tog sin afsked. Som arkivmand har han altid nydt stor anseelse og har fra 1938 været leder af 1 . afdeling, ler omfatter arkivalierne før 1848.

I sine yngre år var dr. Hjelholt stærkt optaget af politik. Men hans arbejde her hørte op, fordi historisk forskning efterhånden helt lagde beslag på hans betydelige arbejdskraft. Han blev stærkt påvirket af begivenhederne $1918-20$ og tog med stor energi fat på at klarlægge vigtige sider af Slesvigs historie $\mathrm{i}$ årene fra 1848 til 1864. I sin disputats $\gg$ Den danske Sprogordning og det danske Sprogstyre i Slesvig mellem Krigene unders $\emptyset$ gte han sprogreskripternes tilblivelse og gennemførelse. Senere søgte han også i værket $\gg$ Treitschke og SlesvigHolsten * at give et bidrag til det slesvig-holstenske spørgsmål gennem en unders $\varnothing$ gelse af den store tyske historikers nationalpolitiske opfattelse og udvikling. I en række artikler i Historisk Tidsskrift, i S $\emptyset$ nderjyske årbøger og andetsteds er han stadig vendt tilbage til sønderjysk historie i tiden mellem krigene, selv om han også har skrevet om andre tidsperioder i landsdelens historie. I det store værk Sønderjyllands Historie, som han var medredakt $r$ af, har han skildret tiden 1660-1805, og han har behandlet det evigt omstridte problem, inkorporationen af den gottorpske del af Sønderjylland 1721, i en særlig bog. Desuden har han været medredakt $\emptyset r$ af værket om Flensborg og er hovedredakt $\varnothing r$ af den kommende bog om Sønderborg.

Dr. Hjelholt har dog også skrevet en del bøger og artikler om almindelig dansk historie. Vægtigst er vel nok hans omfattende bidrag til det store værk om Rigsdagen, hvori han har skildret den almindelige politiske udvikling $\mathrm{i}$ årene $1849-66$, men også tobinds værket om Falsters historie indeholder dybtgående og værdifulde historiske undersøgelser af almen værdi, ikke mindst for landbrugshistorien. 
Dr. Hjelholt nyder stor anseelse indenfor historikernes kreds, og han har efterhånden beklædt en række betydningsfulde stillinger indenfor det historiske organisationsarbejde, ligesom han er medlem af Videnskabernes Selskab og andre lærde societeter. Han har engang $i$ en selvbiografi udtalt, at han $i$ sine historiske arbejder har haft - den historiske sandhed og retfærdighed for фje . Bag dr. Hjelholts rolige ydre gemmer der sig en ikke ringe sindets lidenskab, der også præger hans store kærlighed til grænselandet - både syd og nord for Skelbækken — men i sit arbejde for danskheden, den danskhed, som han føler bedst at st $\varnothing$ tte gennem sin forskning, har han altid villet og kunnet tøjle enhver national lidenskab, og hans værker er ikke blot præget af sund dømmekraft og godt omdømme, men viser også, at hans $\emptyset$ nske om at have sandhed og retfærdighed for фje ikke blot er ord, men har gennemsyret hele hans historiske forskning, hvis metode han $\mathrm{i}$ sin tid lærte hos $\mathrm{Kr}$. Erslev.

Der er grund til, nu dr. Hjelholt står på tærskelen til det, man

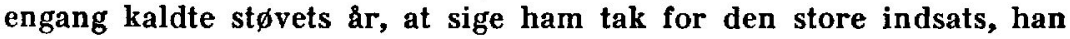
har gjort i udforskningen af Sønderjyllands fortid, men også at ønske ham mange gode arbejdsår fremover. Han har gennem tiderne været en flittig gæst i Sønderjyske årbøger. Vi håber også i fremtiden at få mange bidrag fra hans utrættelige pen.

Johan Hvidtfeldt.

\section{Fem gamle melodibager.}

Historisk samfund har af den gamle musiker Andreas Petersen, forhen Rørkær, nu Kollund, modtaget en meget værdifuld gave, idet han har overladt samfundet fem gamle melodib $\emptyset g e r$, indeholdende mange hundrede dansemelodier, som han og hans forfædre har spillet ved fester på vesteregnen. Melodibøgerne er overladt os på betingelse af, at de forbliver i S $\emptyset$ nderjylland, og de er forel $\varnothing$ big anbragt på landsarkivet i Åbenrå. Men når der måtte blive oprettet en samling her i landsdelen, hvor de mere naturligt måtte høre hjemme, og hvor de kan anbringes under betryggende forhold, vil de blive overflyttet dertil. Adskillige af melodierne har været spillet såvel i den danske som den svenske radio, og det må meget håbes, at sønderjyske folkedanseforeninger også vil forstå at gøre brug af denne kostelige skat. Melodibøgerne kan fås til gennemsyn på landsarkivets læsesal, og for en billig penge vil interesserede kunne få fotokopier af de melodier, som de måtte $\emptyset$ nske at spille $i$ folkedanseforeningerne. Historisk samfund skylder Andreas Petersen megen tak for den tillid, han har vist os ved at overlade os melodisamlingen.

P. K. 1 . 


\section{Nyt fra arkiverne.}

Af landsarkivets erhvervelser i den seneste tid kan nævnes Sønderjydsk Lånefonds og Sønderjydsk Valutaråds arkiver. Om kort tid vil endvidere den nu opløste S $\varnothing$ nderjydske Fonds arkiv blive afleveret. Når disse arkiver engang bliver tilgængelige for forskningen, vil de ikke blot kunne yde værdifulde bidrag til belysningen af landsdelens фkonomiske forhold efter genforeningen, men tillige vil ogsà fremtidens personalhistorikere her kunne hente oplysninger.

Af gårdejer Hans Andersen, Kongsbjerg, har landsarkivet fået overladt dele af Danske Samfunds Arkiv. Der er heri vigtigt materiale til belysning af nationalpolitiske forhold i 1930'erne.

Landsarkivet har endvidere modtaget pastor $N$. A. Jensens og kreditforeningsdirekt $\varnothing \mathrm{r}$, konsulent Hans Hansens efterladte papirer, dele af dagbladet Hejmdals arkiv, Det blandede distrikts landboforenings protokoller, sager fra Den nordslesvigske brandforsikringsforening for bygninger samt en del arkivalier, der hidtil har været opbevaret på Ãbenrå museum.

Grosserer Friis, Århus, har foræret arkivet maskinskrevne fortegnelser over dimittender fra en række seminarier. Af særlig interesse for Nordslesvig er fortegnelsen over de lærere, der er udgået fra Tønder seminarium.

Af arvingerne efter museumsinspektør J. Frost, Åbenrå, har landsarkivet modtaget afd $\varnothing$ des efterladte, betydelige personalhistoriske samlinger, der bl. a. omfatter slægtstavler for mange af landsdelens kendte slægter. Også fra lærer Chr. Maib $\phi l l$, Jejsing, og fra bibliotekar Carl Langholz, Viborg, har landsarkivet i den senere tid modtaget en del maskinskrevne eller duplikerede slægtstavler. En specifikation over disse tavler og grosserer Friis' dimittendfortegnelser vil blive bragt $i$ den planlagte nyudgave af Olav Christensens bibliografi.

Ved $k \varnothing b$ har landsarkivet endvidere erhvervet de af fhv. amtsforvalter Jon. Smith udarbejdede fortegnelser over kongelige tilladelser til hjemmevielser og til ægteskaber mellem beslægtede omfattende tiden 1648-1774. For adskillige sognes vedkommende kan der således nu på en let måde skaffes oplysninger om ægteskabsforbindelser forud for kirkebøgerne, ligesom disse registre ofte kan være til hjælp, når man ikke forud har kendskab til, hvor eller når en vielse har fundet sted. Jon. Smith har udarbejdet fortegnelserne på grundlag af >Patenten « $i$ Tyske Kancelli, fynske og jyske registre i Danske Kancelli samt slesvigske amtsregnskaber. 
Pa landsarkivet forefindes nu alfabetiske registre til kirkebøger og personregistre fra alle fire købstæder (for Sønderborgs vedkommende til dels udarbejdet af lærer Chr. Maibøll, Jejsing), og fra Højer og Løgumkloster flækker; for Christiansfelds vedkommende findes alfabetisk register $i$ kirkebogen, og et register til de nordborgske kirkebøger er under udarbejdelse. For landsognenes vedkommende har landsarkivet forel $\emptyset$ big udarbejdet registre for Bov, Gram og Løjt sogne. For Hørup, Lysabild og Ulkebøl sogne forefindes forskellige registre udarbejdede af Chr. Maib $\emptyset l$, medens A. Korse, Broager, har foræret landsarkivet et register til de viede i Broager omfattende tiden 1695 til 1895.

Flensborgs byarkiv har fra 1. april 1957 fået ny leder, idet arkivassessor, dr. phil. H. Fr. Schütt har overtaget stillingen som byarkivar efter faderen, dr. phil. $O$. Schütt. Danske historikere har altid mødt en enestående hjælpsomhed og imødekommenhed hos $\mathrm{dr}$. O. Schütt, og der skal derfor nu, da han for alvor er trådt over i de pensioneredes kreds, lyde en hjertelig tak til ham. Den nye arkivar, der vil være kendt af adskillige som forfatter til skrifter vedrørende flensborgsk historie, vil vi gerne bringe vor lykønskning $i$ anledning af hans udnævnelse til byarkivar.

I $\emptyset$ vrigt flytter byarkivet dette efterår fra de trange lokaler i Deutsches Haus til den gamle latinskole mellem Klostergangen og Rødegade.

Ved det slesvig-holstenske landsarkiv på Gottorp slot er der 1. april 1957 blevet ansat en arkivar mere, således at den videnskabeligt uddannede stab der nu er på fire mand. Den nye arkivar er dr. Wilhelm Hahn, der tidligere har været tjenstg $\phi$ rende $i$ Landeskanzlei.

$$
\text { P. K. I. }
$$

Det slesvig-holstenske ridderskabs arkiv, som hidtil har været opbevaret i Klostret i Itzehoe (se G. E. Hoffmann: Archivgutschutz und Archivpflege in Schleswig-Holstein s. 13 og 75), er for kort tid siden blevet overf $\varnothing$ rt til Landsarkivet på Gottorp slot. Det er dog ikke uden videre tilgængeligt, idet der skal indhentes særlig tilladelse til benyttelsen. Denne gives enten af professor Rendtorff i Kiel eller af klostrets forstander, grev Brockdorff-Ahlefeldt på Ascheberg i Holsten.

Arkivet blev foreløbig registreret af dr. Kupke i 1915. Der er nu udarbejdet en ny registratur, som dog bygger på Kupkes, men har betydeligt flere numre (ialt 542) end denne. Arkivet indeholder et værdifuldt materiale til slesvigsk og holstensk historie, især efter 1700.

J. $H$. 


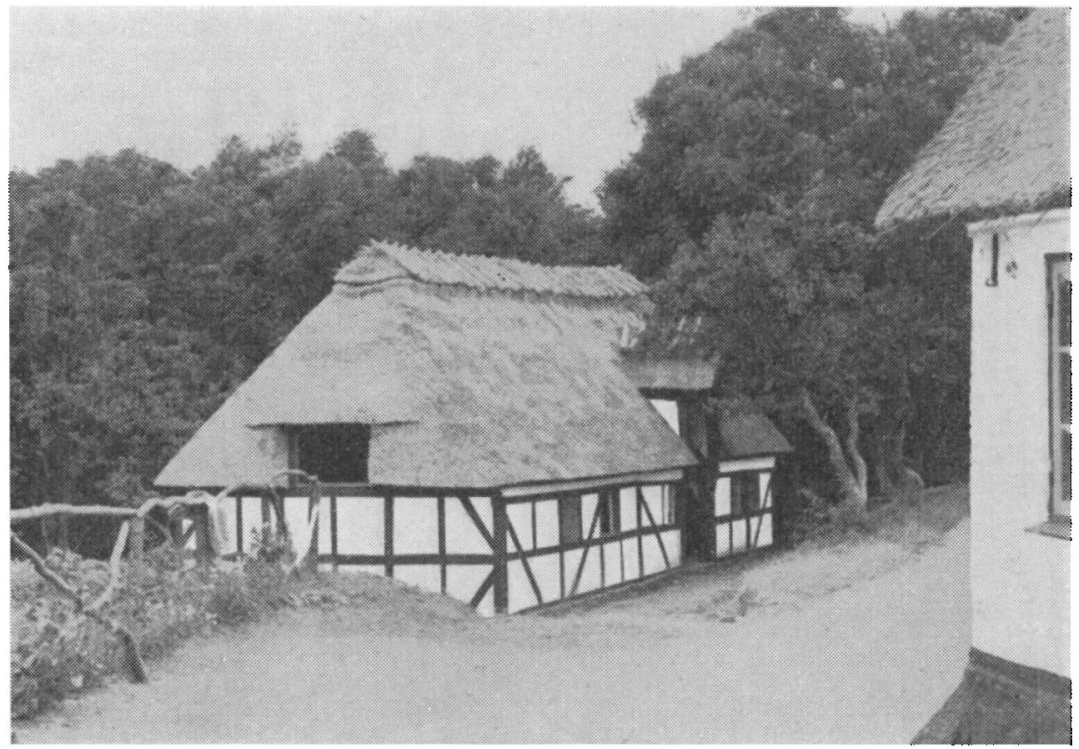

Vibek mфlle. (Fot. A. Jespersen).

\section{Vibak molles restaurering.}

Søndag d. 14. juli 1957 sattes Vibæk mølles store vandhjul atter i gang. Dagen var valgt med vilje: Det var møllens 201 aars fødselsdag. Aaret $f \phi r$, da m $\phi$ llen blev unders $\emptyset \mathrm{gt}$, havde man over indgangsdøren fundet indskriften: ANO MDCCLVI D. 14. JULI DEDH OR. Herved dateredes denne meget interessante m $\phi l l e$ - den sidste vandmølle paa Als, som det endnu var muligt at redde. Og takket være velvilje fra begge ejerinders side, takket være lokale tilskud og dygtigt haandværkerarbejde lykkedes det paa et aar at faa muliggjort og gennemført den gennemgribende restaurering. Arbejdet udf $\varnothing$ rtes under ledelse af ingeniør Anders Jespersen fra Nationalmuseets mølleudvalg, og møllen blev fredet med Nationalmuseet og Museet paa Sønderborg Slot som paataleberettigede, uden at møllens ejendomsforhold berøres derved.

Vibak mølle er if $\varnothing$ lge en indskrift paa en af hovedbjælkerne bygget af Hans Myller af Peberbjerg for J $\varnothing$ rgen Krack og Kiestina Mari Jørgens i 1756. Den blev ved restaureringen fort tilbage til sin gamle skikkelse, idet en senere overbygning og et skæmmende bliktag fjernedes og et højt, smukt straatag genskabtes, ligesom væggene rettedes op, støbejernsvinduerne udskiftedes og vandhjulet sattes i stand, saa- 
ledes at hele møllen nu fungerer som i gamle dage. Møllen ligger i dag ualmindelig idyllisk lige ved det gamle udskibningssted Taskland. Dens historie er yderst veloplyst, bl. a. kendes alle møllere fra 1756 til idag. Ovenikøbet ved man, at det kun er bygningen, der er fra 1756. Selve møllen har oprindelig ligget højere oppe ad bækken, og den kan her følges tilbage til 1710. Da der saa højt oppe dels har været for lidt vand, dels var for langt til havn, flyttedes den til den nuværende plads. Ogsaa her svigtede vandet imidlertid af og til, og man byggede den vindmølle, der endnu hører med, men som nu er ret forfalden. Forhaabentlig lykkes det ogsaa engang at redde den, saa hele det gamle anlæg med det smukke stuehus kan blive bevaret som et smukt minde om de tider, da elektricitet og olie endnu ikke havde udkonkurreret vind og vand som kraftkilder.

J. Slettebo.

\section{Tender Kirkemuseum.}

Egentlig er det et alt for fordringsfuldt navn, og meningen er da ogsaa kun den, at det skal dække over den kendsgerning, at der $i$ Tønder i sommeren 1957 er gjort en beskeden begyndelse til noget, der maaske engang kan blive et virkeligt lokalmuseum for kirkelig kunst i Tønder amt og by.

Kirkemuseet har sin egen bygning med egen indgang, en større og mindre museumssal med god belysning samt en forstue og et rum til oplagring af ting, der endnu ikke kan udstilles. Bygningen ligger i Nørregade, bagved præstegaardene og tilhører Tønder Kirke. Den er opf $\varnothing$ rt i 1890-erne; den største sal har været brugt til konfirmationsundervisning fra da af og indtil 1938.

At denne »konfirmandsal $n u$ er blevet kirkemuseum, skyldes et sanmenst $\varnothing d$ i sin tid af to tilfældigheder. For det f $\varnothing$ rste var det for alle, der havde ansvar for Tønder Kirke og dens ejendom, et bestandigt paany opdukkende problem, hvad der skulde gøres ved den bygning i Nørregade, der kostede kirkekassen penge til vedligeholdelse uden at give nogen indtægt af betydning. Og for det andet voldte det bekymring, hvad der skulde stilles op med 12 legemstore malerier af tidligere præster ved Tønder Kirke. Efter kirkens hovedrestaurering 1940 - 45 var der enighed om, at det var umuligt at finde plads for dem i kirken uden at skæmme eller overlasse denne. En dag dukkede da den ide op: Hvorfor ikke lose begge problemer paa een gang ved at omdanne konfirmandsalen til et kirkemuseum og anbringe præstemalerierne der?

Efter forskellige forhandlinger til flere sider blev en plan med tilhørende økonomiske budget godkendt af kirkeministeriet på den betingelse, at sagen kun skulde betragtes som et $\gg$ midlertidigt ekspe- 


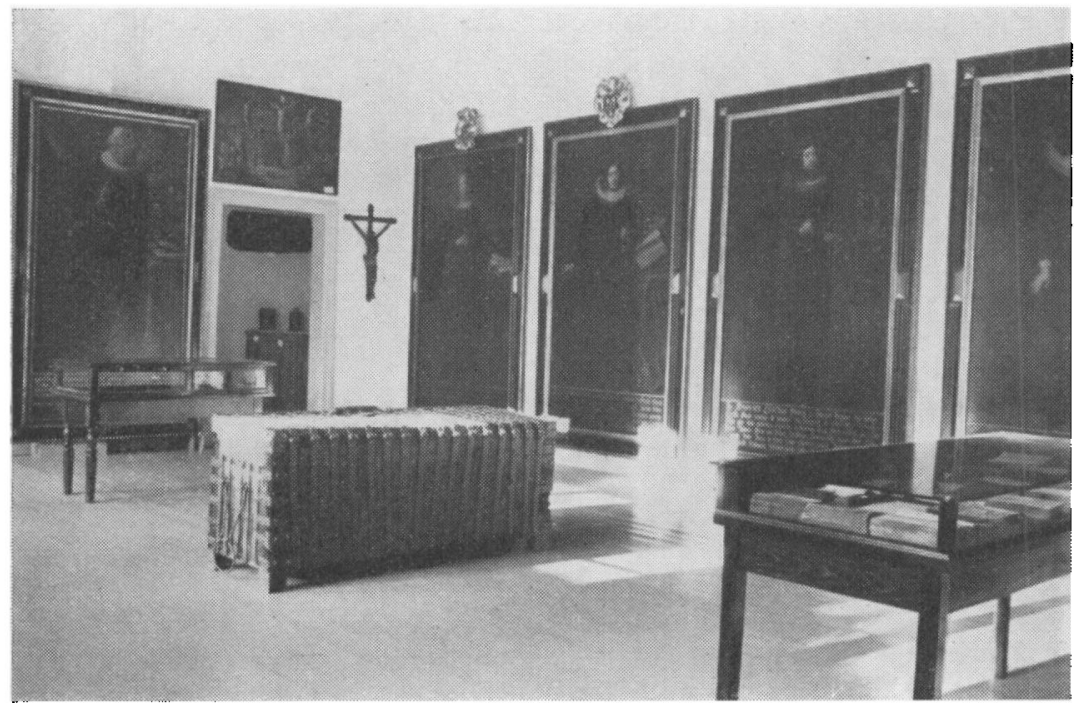

Interiфr fra del nyoprettede kirkemuseum i Tønder.

riment «, og at den kun maatte paaføre den lokale kirkelige ligning en srimelig udgift $\alpha$.

Med denne tilladelse gik vi $i$ gang med at sætte bygningen i Norregade $\mathrm{i}$ stand udvendigt og indvendigt. Det kostede os $\mathrm{kr}$ : $6.833,00$. Beløbet blev skaffet lokalt, men uden een $\emptyset r e$ fra den kirkelige ligning. Og dermed var bygningen klar til at modtage de ting, vi i f $\varnothing$ rste omgang kunde faa samlet.

Da de tolv store prastemalerier var ophængt, viste det sig, at de hang bedre end nogen sinde $f \emptyset r$. Man kan nu se, at flere af disse malerier er god kunst, som det er værd at studere nøjere. I tid spænder de 12 portrætter over ca. 200 aar. De 10 æeldste er malet paa træ, de to yngste paa lærred. Det var altsaa grundstammen i det nye kirkemuseum.

Ved forhandling med bestyrelsen for Tønder Museum var der imidlertid truffet den ordning, at det meste af det, der fandtes af kirkelige kunstgenstande, skulde overf $\varnothing$ res til kirkemuseet. Det drejede sig om to grupper af saadanne ting: (1) genstande, der tilhørte Tønder Kirke, og som hidtil havde været deponeret i museet, samt (2) ting der havde tilhørt forskellige kirker i VestsIesvig, men som enten var blevet overdraget til Tønder Museum eller deponeret der. Den første gruppe fik vi uden videre overdraget, saa at kirkemuseet nu stuar som ansvarlig for disse sager. Den anden gruppe har kirke- 
museet modtaget $\mathrm{i}$ depot med ansvar for disse ting overfor Tønder Museum eller den paagældende kirke. Endelig har kirkenuseet som en tredie gruppe modtaget en hel del mer eller mindre værdifulde ting fra andre kirker $i$ Tønder amt samt fra private personer dels som kirkemuseets ejendom og dels som deponerede.

Foruden de store præsteportrætter omfatter kirkemuseet paa nuværende tidspunkt følgende kirkelige effekter:

(1) En egetræsgruppe fra den middelalderlige kirke i Tønder, Sct. Nicolai Kirke, forestillende Sct. Helena, der finder det underg $\phi$ rende kors. Skulpturen har antagelig staaet paa et sidealter og maa vel dateres til det 14. aarh. Af ting fra middelalderen findes tillige en stor egetræs kirkekiste med jernbeslag, tilhørende Visby Kirke, hvor den blev fundet af Nationalmuseets folk og nu er erhvervet af kirkemuseet og konserveret. Den er med sine kraftige jernbeslag en af museets mest dekorative genstande.

(2) Som det dernæst mest iøjnefaldende kan nævnes en hel række forskellige pulpiturfyldninger og stoled $\varnothing$ re fra mange forskellige kirker i Vestslesvig, alle fra tiden efter reformationen og de fleste fra baroktiden.

(3) I en lukket glasmontre er anbragt eksemplarer af de fleste danske og en del tyske salmeb $\emptyset g e r$, som har været benyttet $i$ Nordslesvig siden reformationen. Der mangler dog nogle endnu, f $\phi r$ vi har en fuldstændig samling.

(4) Endvidere findes en del kisteskjolde, en hel del forskellige træskulpturer (det meste fra baroktiden), en gammel messehagel (alderen endnu ikke sikkert bestemt), et par daabskander, nogle malerier og fotografier, et par gamle pauker (fra Tønder Kirke), en gammel egetræs kirkeb $\phi s s e$ med beslag $\mathrm{m}$. $\mathrm{m}$.

Alt er museumsmæssigt ordnet med opmaaling, beskrivelse og katalogisering, og hver af de udstillede genstande er forsynet med et kort med oplysninger for de besøgende. Pensioneret lærer Christensen, tidligere Burkal, har paa dette omraade ydet museet en uvurderlig hjælp. Salmebogsmontren er ordnet af pastor Malling. Ligeledes har vi fået megen hjælp af museumsinspektør, magister Schoubye.

Forretningsudvalget indenfor Tønder Menighedsraad har ansvaret for kirkemuseets ledelse. Man har lagt et budget for museet, hvorefter det vil kunne opretholdes for ca. $1400 \mathrm{kr}$. aarligt, og der regnes med, at driften af kirkemuseet ikke vil komme til at belaste den lokale kirkelige ligning.

Allerede nu er det anbefalelsesværdigt at aflægge dette lille begyndende museum et bes $\phi$ g. Der er baade noget at beundre og noget at lære. Men dersom det skal blive mere end en beskeden begyndelse, maa menighedsraad, institutioner og private personer interessere sig 
for det. Adskillige steder ligger der sikkert endnu værdifulde ting gemt hen mer eller mindre upaaagtet, - - malerier, skulpturer, gamle salmeb $\emptyset$ ger $\mathrm{m}$. $\mathrm{m}$. - - som først vil faa rigtig betydning og værdi, naar de bliver anbragt under betryggende forhold og $\mathrm{i}$ de rette tidsmæssige omgivelser. Der er allerede nu ting her, hvorom det gælder, at de inden mange aar vilde vare smuldret hen og gaaet til grunde, dersom vi ikke havde faaet dem betroet.

Hans Magle.

\section{Genforeningsværelset på Sonderborg Slot.}

Af de mange værelser paa Museet paa Sønderborg Slot er et viet mindet om genforeningen. Her staar Chr. X's uniform, her hænger Alfred V. Jensens store genforeningsbillede, L. Tuxens billede af Chr. X til hest paa Christiansborgs ridebane, fotografier og plakater fra afstemningstiden, C.I.S.-uniformer, n $\emptyset$ dpengesedler, en alpejægeruniform og et billede af general Moltke, der havde kommandoen over det sønderjyske kommando. Dette værelse er i foraaret blevet sat i stand, og en del ting, der ikke direkte havde med genforeningen at gøre, flyttedes til andre rum. Resten nyopstilledes, og et par fornemme gaver fik plads i samlingen: Sadlen fra den hvide hest, som bar kongen over grænsen, er af grevinde $M$. Brockenhuus-Schack, Barritskov, blevet foræret til museet. $O g$ S $\emptyset$ nderjydsk Fond, der har bekostet hele rummets reparation, har skænket en hel række gaver: To af de konfirmationsure, som fondet igennem mange aar har givet til børn, hvis fader faldt i f $\not$ rste verdenskrig, en samling postkort med gengivelser af plakater og en samling fotografier fra genforeningsdagene, en brevpresser, dannet af et haandtag fra en af de gamle bronzekanoner, der blev brugt til omsmeltning til kirkeklokker til sønderjyske kirker. Og endelig den fornemste gave: En mindetavle over Sønderjydsk Fonds virke. Den bestaar af to dele, nederst en montage med fotografier fra møder $i$ fonden og teksten til det oprindelige opraab om indsamling, grupperet om bestyrelsens dirigentklokke, en model af en kirkeklokke, og $\emptyset$ verst en teaktræstavle med en indskrift i oph $\varnothing j e t$ relief. Tavlen er anbragt saa den $i$ et stærkt sidelys kommer fuldt til sin ret, og teksten fremtræder letlæselig. Indskriften lyder:

Med tilslutning fra alle kredse $\mathrm{i}$ vort land

blev

DEN SøNDERJYDSKE FOND

stiftet paa Carlsberg den 7. december 1918.

Den modtog som gave fra det danske folk, en sum, der med renter beløb sig til ca. 15,5 mill. kr. som hjælp for danske i det af verdenskrigen i 1914-1918 ramte Sønderjylland. 
Fondens midler er blevet anvendt nord og syd for vor nuværende grænse til følgende formaal:

Hjælp til krigsinvalider og faldnes efterladte 10,34 mill. kr. Til syge 1,21 mill. kr. - Til skoleophold og anden uddannelse for unge 2,39 mill. kr. - Til kirker og krigerkirkegaarde 0,32 mill. kr. - og til forskellig anden hjælp 1,25 mill. kr.

Fonden sluttede sit virke den 7. december 1953.

J. Slettebo.

I $E j s b \phi l$ mose ved Haderslev er udgravningen af det store mosefund fortsat $i$ år. Et areal på ca. $170 \mathrm{~m}^{2}$ er undersøgt, og over 1000 genstande er fremdraget. Allerede nu har Ejsbøl-fundet dermed nået Illerup-fundet i størrelse og er et af landets få store våbenfund fra yngre romertid (300 årene e. Kr. f.).

Det er et krigsbytte fra et slag, hvor helt eller delvis beredne hære har kæmpet, der her er ofret. Byttet er brændt, og i mosen ligger metaldelene af sværd og sværdskeder, af spyd og skjolde og af hestenes selet $\varnothing$ j. Særlig flotte er bidslernes broncekæder og sværdfæsternes s $\emptyset l v-$ beslag.

Da findestedet ikke er udtømt, er det meningen at fortsatte undersøgelsen til næste år.

H.N.

Under ledelse af arkitekt Charles Christensen har Nationalmuseet i sommer foretaget betydelige udgravninger og restaureringer ved Trøjborg. Udgravningerne har givet betydningsfulde bidrag til borgens bygningshistorie, og der er fra voldgravene fremdraget adskilligt materiale.

Ved Løgumkloster er der ligeledes under ledelse af arkitekt Christensen foretaget udgravninger og opmålinger på det terræn op mod klosteret, som det nye refugium vil komme til at berøre. Udgravningerne har givet meget stof til belysning af klosteranlæget. - Sønderjyske årbøger håber at kunne bringe afhandlinger om disse to arbejder $i$ et kommende hefte.

I løbet af foráret er der foretaget en nyopstilling af Haderslev Amts Museums stenalder- og broncealdersamling. Det er fors $\phi$ gt at gøre den nye udstilling mere instruktiv og overskuelig. Fremhæes må en gibsmodel af en langdysse; den kan skilles ad, så den viser, hvorledes denne langdysse har udviklet sig $i$ århundredernes løb. Et træ fældet med en flintøkse skal ligesom andre skæftede og brugte ting vise, hvad flintværkt $\varnothing \mathbf{j}$ kunne bruges til.

Nyindretningen skal senere fortsættes $\mathrm{i}$ de andre afdelinger. 
Et nyt museum er under oprettelse i Jels. I nogle år er der arbejdet med indsamlingen, og en udstilling for et år siden viste befolkningens interesse for sagen. Samlingen, der både omfatter oldsager og nyere ting, har endnu en for spredt karakter til, at en udstilling kan foretages. Den har til huse på skolen.

På foranledning af bestyrelsen for Vojens Handels- og Industriforening ved foreningens 75 års jubilæum den 25. august 1957 vistes bl. a. en udstilling af gamle og nye Vojens-billeder: bydele, huse og personer. Den ret righoldige samling var indsamlet og ordnet af pastor T. Holm og forhv. arkivar J. Aalling, Vojens. Udstillingen vakte levende og stor interesse blandt de godt 600 besøgende. Måske bliver udstillingen gentaget, og en fremsat plan om at bevare en væesentlig del af billedsamlingen samlet $-\mathrm{f}$. eks. i sognebibliotekets lokaler - kan muligvis realiseres.

Museet på Sønderborg Slot havde i finansåret 1956/57 rekordbes $\phi g$, idet over 60.000 bes $\phi g t e$ museet. Dette skyldes dels stigende turistbes $\emptyset \mathrm{g}$ i Sønderborg, dels den store udstilling, Selskabet til Håndarbejdets Fremme afholdt på museet fra d. 22. juni til d. 12. august 1956. Rekorden falder sammen med, at der over hele landet har været stigende museumsbes $\emptyset \mathrm{g}$.

Af nyerhvervelser til museet $\mathrm{i}$ årets løb kan nævnes 12 par kopper, udført som gave til den i Gråsten fødte historiker A. D. Jørgensen fra taknemmelige sønderjyder, 6 miniaturer, tegnet af H. P. Feddersen d. $\mathbf{E}$. og et standur, lavet i Hønsnap. Kunstsamlingen har erhvervet et billede af Jeppe Madsen-Ohlsen.

Efterhånden som museumsbestanden på Tønder Museum vokser og mere og mere fuldstændigg $\phi$ res, bliver opgaven at bevare og konservere det indkomne materiale, give det de smukkest mulige omgivelser nok så vigtigt som at anskaffe mere nyt. Disse synspunkter præger $\mathrm{i}$ højeste grad arbejdet ved Tønder Museum, hvor $\mathrm{i}$ den seneste tid omfattende arbejder med hensyn til bygnings- og haveanlægs vedligeholdelse har fundet sted. Yderligere er det et karakteristisk nytræk, at man i stedet for at indsamle materiale fra alle mulige områder, foretrækker specialisering, $g \varnothing r$ en gruppe færdig ad gangen. Således må museets indsamling af $\mathrm{f} l$ is e $\mathrm{r}$ i det store og hele siges at være afsluttet, af den simple grund at der ikke er mere tilbage af betydning i museets virkeområde, i hvert fald intet der f. t. kan erhverves. De sidste to år har man da koncentreret sig om indsamlingen af $s \phi l v$ fra Tønder og Tønder amt, hvilket har givet et overraskende godt udbytte. Museet besidder nu henved $200 \mathrm{~s} \emptyset \mathrm{lv}$ - (og guld-) arbejder fra byen og dens opland, repræsenterende henved 60 forskellige mestre, og sam- 
lingen er i løbet af sommeren udstillet i 5 store, moderne indrettede montre. Den $t \varnothing r$ vist uden tvivl betegnes som den største af sin art i landet. At dette resultat er nået på så kort tid, skyldes ikke mindst heldigt gennemf $\phi$ rte bytteaftaler med en lang række museer, som havde s $\varnothing$ lv fra T $\phi$ nder.

Abenrå Museum har i 1955 haft ca. 2.900 besøgende og i 1956 ca. 2.700 bes $\emptyset$ gende. Den vigtigste nyerhvervelse er Løjtstuen, som Sønderjydske årbøgers forårshefte har bragt en udførlig omtale af.

I 5. årgang af Jahrbuch für die Schleswigsche Geest har professor Hans Beyer i Flensborg $\mathrm{i}$ en lille undersøgelse $\rightarrow$ Recht, Volk und Obrigkeit in der schleswig-holsteinischen Erhebung 1848/49 c gjort et fors $\emptyset g$ på at nå frem til en mere psykologisk forståelse af begivenhederne i 1848. Han mener, at den »nationale ideologi\& ikke har været af afgørende betydning, $i$ hvert fald ikke for menigmand. Viljen til at f $\varnothing$ lge f $\emptyset$ rerne $i$ »rejsningen var f $\emptyset$ rst og fremmest afhængig af den stærke følelse af ret og uret. For at forstå, hvad der skete, må man også gøre sig klart, hvad der var »virkelighed $i$ modsætning til politikernes ideologi; folket var en virkelighed, kirke, skole og torv ligeledes, og i Sydslesvig var præstens, degnens og handelens sprog tysk.

Man kan være enig eller uenig med professor Beyer $i$ hans synspunkter, men artiklen, der bygger på omfattende studier, også i ikke-tyske arkiver, er i hvert fald tankevækkende og inspirerende. Den giver også værdifulde bidrag til forståelse af førende kirkelige personligheders stilling til det, der skete $\mathrm{i}$ og efter 1848, og til deres opfattelse af, hvad der, set fra deres bestemte synspunkt, måtte anses for ret eller uret. Der er tale om folk som pastor Hans Hansen, Claus Harms, provst Callisen og generalsuperintendent Nic. Nielsen.

J. $\boldsymbol{H}$.

Historisk samfund arrangerer $\mathrm{i}$ vinter aftenkursus på landsarkivet i Abenrå i vejledning i personal-og lokalhistorisk arbejde. Som vejledere medvirker fuldmægtig Olav Christensen og museumsinspekt $\varnothing r$ H. Neumann, begge Haderslev, arkitekt Karl Flade, Åbenrå, landsarkivar Gribsvad og arkivar Iversen. Tilslutningen til kursus har været så stor, at der har måttet oprettes 3 hold.

I slutningen af september er der til Historisk samfunds tillidsmænd udsendt en vejledning vedrørende oprettelse af aftenhøjskoler med hjemstavnshistorie som emne. Formanden for Haderslev amts museumsog byhistorisk forening, museumsinspektør H. Neumann har sendt en lignende opfordring, og det kan allerede nu siges, at disse henvendelser har båret frugt, idet der $i$ adskillige sogne er oprettet sådanne aftenhojskoler. 


\section{Årsberetning og regnskab $1956-1957$}

ved Peter Kr. Iversen og Olav Christensen.

Årsmødet afholdtes søndag d. 26. maj på Slogsherredhus, hvis store sal var fyldt. Formanden, arkivar P. Kr. Iversen, bød velkommen, specielt til samfundets æresmedlem, H. Lausten-Thomsen, og takkede Slogsherredhus, fordi årsm ødet kunne afholdes her. Efter en fællessang valgtes redakt $\phi r$ M. Kamphфvener, Abenrå, til mødets dirigent. Formanden aflagde, efter at han havde indledt med at mindes gdr. Sv. Anker Hanssen, Nørrem $\varnothing l l e$, f $\varnothing$ lgende beretning:

Den omorganisering af Historisk samfund, der tilsigtedes med de nye love, som vedtoges på årsmødet i Gram 1955, er nu med oprettelsen af amtskredsen for S $\phi$ nderborg amt d. 26. april i år gennemf $\varnothing r t$. Og det kan vist uden modsigelse fastslås, at der ved den nye organisationsform er kommet mere liv over Historisk samfunds arbejde. De nye amtsudvalg og det under dem sorterende og nu næsten helt udbyggede tillidsmandssystem har arbejdet godt og målbevidst. Når bortses fra Sønderborg amt, har der i hvert af amtskredsene været afholdt 2-3 arrangementer inden for beretningsåret, og flere af dem har haft en tilslutning over forventning, i Haderslev amt således med 150-200 deltagere. Gennem amtsudvalgenes arbejde er Historisk samfunds m $\varnothing$ devirksomhed blevet meget $\varnothing$ get. Medens vi tidligere kun havde et foredrag $\mathrm{i}$ forbindelse med årsm $\varnothing$ det og vor sommerudflugt, har amtskredsene sidste år tilsammen haft 12 foranstaltninger. Udførlige beretninger herom er aflagt på amtskredsenes generalforsamlinger, hvorfor de ikke skal nærmere omtales her.

Den gennemførte omorganisering har også medført en betydelig tilgang af nye medlemmer. For to år siden lå vort medlemstal på omkring 1150, i dag har vi omtrent 1600 medlemmer, altså en tilgang på 450 nye medlemmer, som vi gerne vil byde velkommen $i$ vor kreds. Denne tilgang af nye medlemmer havde ikke kunnet nås uden et godt og dygtigt ført hvervearbejde af amtsudvalg og tillidsmænd. Jeg benytter den her givne lejlighed til at sige tak til alle, der har medvirket ved medlemstilgangen.

Medlemmerne vil have bemærket, at $\$ \varnothing$ nderjyske årbøger har fået et nyt ydre. Der blev på sidste årsmøde anket over, at vore publikationer havde et trist udseende. Vi håber, at vi nu for Sø̆nderjyske 
årbøgers vedkommende har tilfredsstillet vore kritikere. Det kan i denne forbindelse nævnes, at det er hensigten, at der fremstilles en ny forsidekliche til hvert halvbind. Det er også vor hensigt på anden måde at gøre Sønderjyske årbøger lidt mere interessante. Ligesom i det nyligt udkomne forårshæfte vil vi også fremtidig søge at bringe nogle flere illustrationer, ligesom vi også i hvert hæfte vil søge at bringe et par mindre artikler.

Også vort andet tidsskrift, Sønderjysk månedsskrift, er, som det senere vil blive udførligere redegjort for, inde $i$ en opgangsperiode, idet tidsskriftet siden sidste årsmøde har haft en tilgang på ca. 60 nye holdere.

Med hensyn til vore publikationer inden for skriftrækken vil medlemmerne vide, at der $\mathbf{i}$ vinter er udsendt en bog af adjunkt $H$. V. Gregersen om præsten, astrologen, forfatteren og journalisten Niels Heldvad. Det er en god bog, og anmeldelser i dagblade og tidsskrifter har da også været enestående rosende. Vi har endnu ikke helt fået inddækket omkostningerne ved udgivelsen af bogen. Bestillingskortene var indlagt $i$ efterårshæftet af Sønderjyske årbøger, der udkom nogle dage før jul, og det er meget muligt, at ikke fả $i$ juletravlheden har overset det. Men det fors $\phi$ mte kan endnu indhentes. Vi venter, at mange vil benytte sig af dette tilbud på god og interessant historisk læsning ved at indsende bestilling til ekspeditionen.

Inden så længe vil manuskriptet til en ny bog inden for skriftrækken blive indleveret til trykkeriet. Det er Åbenrå-kaptajnen Hans Bruhns interessante erindringer, der udgives af Erland Møller og Johan Hvidtfeldt. Når Historisk samfund har mulighed for at udsende denne bog, skyldes det især den velvilje, som forskellige åbenråske firmaer og institutioner har vist os. Vi har fra dem modtaget eller fået lovning på understøttelse til udgivelsen, således at vi kan udsende bogen uden synderlig $\varnothing$ konomisk risiko for foreningen. Jeg benytter lejligheden til at takke for underst $\varnothing t t e l s e n$, vi har modtaget eller har løfte om til bogens udgivelse.

Inden næste årsmøde regner vi endvidere med, at 2 . del af redaktør A. Svenssons store værk om redakt $\emptyset r$ Jens Jessen vil være udsendt. Den $\emptyset$ konomiske side af sagen er her ikke helt klaret endnu. Det kan nu oplyses, at værket vil blive på ialt tre bind.

Af andre ting, der er under forberedelse, kan næunes, at forstander, dr. theol. Asger Nyholm, Tønder, til redaktionen har indleveret et stort manuskript om pastor Dahl og skoleforholdene i Tønder i mellemkrigsårene. I dette grundige og flittige arbejde giver $\mathrm{dr}$. $\mathrm{Ny}-$ holm også værdifulde og nye oplysninger om klosterpolitikken. Vi håber meget, at det vil lykkes os at fremskaffe de forn $\varnothing$ dne penge til udgivelsen af denne bog. Seminarielærer, magister Sig. Schoubye, Tønder, er langt fremme i studiet af de tønderske sølvsmede, som vil 
resultere $\mathrm{i}$ et billedværk, som vi ligeledes håber at kunne udsende i skriftrækken. Arbejdet med Åbenrå bys historie er nu godt i gang, og 1. bind forventes at være klar til udsendelse til efteråret 1959. En anden opgave, hvis fuldendelse dog ligger nogle år fremme i tiden, er. ligeledes under forberedelse, idet overarkivar, dr. phil. Harald Jørgensen har påtaget sig at udgive den vigtige og betydningsfulde brevveksling mellem H. P. Hanssen og $H$. V. Clausen. Det er tanken, at denne publikation skal udsendes til 100-årsdagen for $\mathrm{H}$. P. Hanssens. f $\varnothing$ dsel, d. 21. febr. 1962. Endvidere kan det nævnes, at Historisk samfund i samarbejde med Udvalget for udgivelse af kilder til landbefolkningens historie forbereder udgivelse af jordeb $\emptyset$ ger fra Åbenrå og Løgumkloster amter fra begyndelsen af 17. og 18. århundrede. Historisk samfund har af $\phi$ konomi- og arbejdsministeriet fáet bevilget en såkaldt henvist kontorist, der fra januar har afskrevet en betydelig del af de omtalte jordebøger og endvidere har foretaget visse forarbejder til en topografisk historisk bibliografi. Og endelig kan det nævnes, at vi omgås med planer om en nyudgave af Olav Christensens bibliografi over sønderjysk slægtstavlelitteratur kombineret med en fortegnelse over personalhistoriske håndskrifter i landsarkivet.

En side af vor virksomhed, vejledning i lokalhistorisk arbejde, har vi desværre været n $\emptyset$ dt til at lægge på hylden $i$ det sidste par år, men det er meget vigtigt for det lokalhistoriske arbejdes fremtidige trivsel, at vi igen får afholdt små vejledende kursus. Vi havde håbet nu $i$ sommer at kunne gennemf $\phi$ re et 14-dages kursus for særligt interesserede seminarieelever og yngre lærere, men det er ikke lykkedes os at skaffe de fornødne penge til afholdelse af et sådant kursus. Vi vil nu g $\varnothing$ re et nyt fors $\varnothing \mathrm{g}$ for om muligt at kunne afholde det til næste sommer. Til vinter håber vi at kunne gennemføre et mindre kursus af lignende art, som vi tidligere har haft, og måske kan der også blive tale om et aftenkursus, hvortil $i$ hvert fald de nærmest omkring Åbenrå boende kan være med. Forholdene for det lokal-historiske arbejde her $i$ Nordslesvig er jo nu engang vanskeligere end i kongeriget. Vel er de ældre arkivalske kilder overalt skrevet med gotisk skrift, men her i S $\varnothing$ nderjylland er sproget i de gamle aktstykker yderligere $\mathbf{i}$ overvejende grad tysk. Vanskelighederne bliver derfor hernede mangedoblede for lokalhistorikerne, især da kendskabet til tysk er i stærk aftagen. Det er derfor af afgørende betydning for det lokalhistoriske arbejde her i landsdelen, at det vejleden-. de arbejde intensiveres og udbygges. Et sådant vejledende arbejde kræver ikke blot penge, men også tid, og med det omfang, Historisk samfunds arbejde efterhånden har fået, ligger den tanke nær, at vi må stræbe henimod at få en fast, lokalhistorisk konsulent ansat, som kan vejlede vore lokal- og sognehistorikere og være dem behjæl- 
pelig med udarbejdelsen af manuskripter til sognehistorier og skrive særligt vanskelige kapitler deri. Dernæst skulle han også være til rådighed for redaktionsudvalgene og den samlede styrelse som hjælpesekretær. Der er mere end arbejde nok til en sådan mand, men det er vel tvivlsomt, om vi i disse sparetider kan skaffe penge til aflonning af ham.

Vor egnsvandring $i$ september sidste år fik et vellykket forl $\emptyset b$. Over 400 deltagere fik efter en kort orientering af museumsinspekt $\phi r$ H. Neumann Glyksborg slot forevist af lokale førere. Museumsdirektør, dr. phil. Fritz Fuglsang, viste os derefter og fortalte levende og interessant om Mariekirke i Flensborg, Pastor H. F. Petersen fortalte om Helligåndskirken og Helligåndsgangen og redakt $\varnothing r$ L. P. Christensen dvalede på den gamle kirkegård ved de minder, der er knyttet til denne. Forinden havde han under kaffepausen i Borgerforeningen fortalt trak af denne danske foreningsbygnings historie. Desværre var der og kunne der ikke være dækket til alle deltagerne i Borgerforeningen, da deltagerantallet var betydeligt større end antallet af tilmeldte. Vi er glade for, at så mange slutter op om disse udflugter, men vi henstiller meget, at medlemmerne tilmelder sig i god tid. Vi vil også i fremtiden søge at gøre disse udflugter så interessante og afvekslende som muligt, men for at disse store arrangementer ikke skal bryde sammen og ende $i$ kaos, er det nødvendigt, at vi på forhånd kender deltagerantallet og kan træffe vore forholdsregler derefter.

Det er mange og for hovedpartens vedkommende også store opgaver, som vi vil søge løst i de kommende år. Det kan ikke gøres uden betydelig støtte ude fra. Vi har hidtil modtaget og modtager understøttelse fra købstæder, amtsråd og stat. Vi er de bevilgende myndigheder stor tak skyldige for denne hjælp, uden hvilken vort arbejde ikke ville have fảet det omfang, det har i dag. I sidste årsberetning omtaltes, at der var planlagt en henvendelse også til sognekommunerne om støtte til vort arbejde. På grund af kommunernes anspændte $\emptyset$ konomi nu i vinter og forårsmånederne har forretningsudvalget imidlertid anset det for rigtigst at se tiden lidt an med disse henvendelser.

Vi har styrket vor $\emptyset$ konomi og arbejdsmuligheder ved det $\emptyset$ gede medlemstal, men der skulle være gode muligheder for at satte det yderligere i vejret. Hvad der for få år siden ville synes fantasteri, ligger nu takket være vor nye organisationsform inden for mulighedens grænse. Vi må i løbet af de nærmeste år søge at nå et medlemstal på 2000. Dette mål kan nås, når amtsudvalg, tillidsmænd og medlemmer fremdeles vil gøre en indsats. Der tales nu og da om svigtende historisk interesse, men er det rigtigt? Er der ikke snarere tale om en slumrende interesse, der blot skal vækkes ved en ydre til- 
skyndelse? Hvor der sættes aftenhøjskoler med historiske og lokalhistoriske emner i gang, er der overalt stor tilslutning; det samme gælder de såkaldte hjemstavnsaftner. Det, det kommer an på, er blot at få et arbejde ude $i$ sognene sat igang, og her må styrelse, amtsudvalg og tillidsmænd arbejde hånd $i$ hånd, men der kan ingen tvivl være om, at hvor der gøres et arbejde, der giver det også resultat - også $i$ form af tilgang af nye medlemmer.

Derefter aflagde kassereren, fuldmægtig Olav Christensen, regnskabet. Han fremhævede medlemsfremgangen og næunte resultatet af årets hvervekonkurrence, hvor sagf $\phi$ rer Poul Fink og bibliotekar H. Eriksen fik f $\phi$ rstepræmier for henholdsvis 36 og 30 nye medlemmer. Både beretning og regnskab godkendtes enstemmigt. Viceskoleinspekt $\varnothing \mathbf{r}$ W. Christiansen aflagde beretning og regnskab for Sønderjysk månedsskrift. Efter flere års stilstand er antallet af abonnenter atter steget, og takket være stor sparsommelighed, bl. a. overfor klicheer og honorarer, klarer månedsskriftet sig nu $\emptyset$ konomisk. En yderligere tilgang af holdere er dog stadig påkrævet. Året sluttede med et overskud på 416,- kr.

Ved det efterf $\phi$ lgende valg genvalgtes forstander $H$. Lund, museumsinspekt $\varnothing \mathbf{r}$ H. Neumann og lærer Chr. Stenz. Kontingentet fastsattes uforandret til $7,50 \mathrm{kr}$. plus portoen til årbogen. På forespørgsel oplyste kassereren, at det vil koste ca. 12,- kr. mere i kontingent at sende månedsskriftet til alle medlemmer.

Under eventuelt takkede gartner Chr. Jepsen, Bylderup, fordi årsmødet var lagt $\mathrm{i}$ Slogsherredhus. Han mindede om, at mange af de danske forsamlingshuse nu er over 50 år, og at det slægtled, der skabte dem er ved at uddø. Han spurgte, om det ikke var en opgave for Historisk samfund at samle minderne om dette arbejde, inden det var for sent. M. Refslund Poulsen undrede sig over, at man kritiserede årbøgerne og månedsskriftet. Begge var vardifulde og fine. Han efterlyste en grundig skildring af »de blakkede«, inden det blev for sent, og af Foreningen af 18. okt. 1898, hvorom der intet skriftligt foreligger, og hvor hrs. Bülow vistnok er den eneste levende fra da. P. Kr. Iversen takkede gartner Jepsen og Slogsherredhus og han takkede for de foreslåede emner, som man vilde søge at tage op. Han foreslog, at næste årsmøde blev holdt i Flensborg, i Borgerforeningen. H. F. Petersen så meget gerne mødet afholdt i Flensborg. Red. Kamphøvener efterlyste kreditforeningens protokol, og efter at Olav Christensen havde gjort opmærksom på, at der stadig var skrifter til salg, og at en del var medbragt til mødet, sluttede Kamphøvener generalforsamlingen. 
Ved det efterfølgende kaffebord talte overarkivar, dr. phil. Harald Jørgensen om: $\gg$ Det nordslesvigske spørgsmåls rejsning på fredskonferencen i 1918 «. Efter kaffebordet foreviste pastor H. M. Detlefsen Bylderup kirke.

\section{Årsregnskab og status pr. 31. 12.1956}

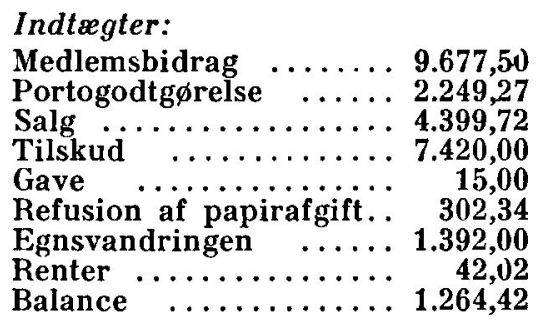

$26.762,27$

Aktiver:

Post- og bankkonti ... 1.864,07

Kontant .......... 11,32

Kontingentrestancer $\quad \ldots \quad 765,00$

Udestående for salg $\ldots . .388,00$

$3.028,39$
Udgifter:

Årbogen :

Papir og tryk 9.451,80

$\begin{array}{llll}\text { Honorarer } \quad \ldots & 2.634,00 & 12.085,80\end{array}$

Skrifter $\quad \ldots \ldots \ldots \ldots \ldots \quad 5.803,09$

Ekspedition, sekretær,

kasserer .......... 850,00

Fragt og omdeling .... 2.682,27

Møder og repræsenta-

tion $\ldots \ldots \ldots \ldots \ldots \ldots{ }^{1.169,17}$

Amtsudvalgene $\quad \ldots \ldots \ldots \quad 1.723,23$

Kontorhold $\ldots \ldots \ldots \ldots$ 801,40

Egnsvandringen $\ldots \ldots, \quad 1.272,81$

Forskelligt

374,50

$26.762,27$

\section{Passiver:}

Regninger $\ldots \ldots \ldots \ldots \quad 1.614,05$

Formue.$\ldots \ldots \ldots \ldots \ldots$ 1.414,34

$3.028,39$

Haderslev, den 8. februar 1957.

\section{Olav Christensen.}

Undertegnede af Historisk samfund for S $\varnothing$ nderjylland valgte revisorer har d. d. revideret ovenstående regnskab, som vi har befundet $i$ orden og $i$ overensstemmelse med foreliggende bilag. Kassebeholdningen pr. 31. december 1956 forelå. Yderligere har vi kontrolleret regnskabet for 1957 indtil d. d. og har intet at bemærke.

p. t. Bylderup, den 26 . maj 1957. 


\section{Medlemskredsen}

\section{Afgang og tilgang}

Efterf $\varnothing$ lgende supplement til den i 1955 og 1956 offentliggjorte medlemsfortegnelse for Historisk samfund for S $\emptyset$ nderjylland er for afgangslistens vedkommende ordnet alfabetisk, medens tilgangslisten er ordnet topografisk, som medlemslisten i 1955 var det. Afgangslisten omfatter foruden d $\varnothing \mathrm{de}$, hvor enken ikke har fortsat medlemsskabet, desuden udmeldte og slettede på grund af restancer. I $\varnothing$ vrigt henvises til indledningen til medlemslisten 1955, idet det dog bemærkes, at kassereren har ansvaret for udarbejdelsen af tillægget.

Historisk samfund har siden sidste års opgørelse haft en nettotilgang af 254 medlemmer, idet medlemstallet pr. 15. september 1957 udgjorde 1623, der fordeler sig således på landets enkelte dele:

Åbenrå by $\ldots \ldots \ldots \ldots \ldots 169$

Åbenrå amt ........... 174

Haderslev by . . . . . . . 97

Haderslev amt $\ldots \ldots \ldots 264$

S $\varnothing$ nderborg by $\ldots \ldots \ldots \ldots, 44$

Sønderborg amt....... 108

Tønder by $\ldots \ldots \ldots \ldots \ldots .89$

Tønder amt $\ldots \ldots \ldots \ldots 196$

Sydslesvig $\ldots \ldots \ldots \ldots \ldots 197$

Stor-København ........ 112

Det $\varnothing$ vrige Danmark ..... 172

Udlandet $\ldots \ldots \ldots \ldots \ldots, 1$

\section{Afgangsliste}

Andresen, Kathrine, fru, Hyllerup, Flensborg kreds

Bak, Jens, skoleinspekt $ø r$, Nr. Sundby

Beck, Hans turistchef, Sønderborg $\dagger$

Biblioteket, Røllum skole

Blichfeldt, præst, Nordborg †

Christensen, Helge M., kommunelærer, Sønderborg
Christensen, Niels, overlærer, Flensborg $\dagger$

Christiansen, Otto, bankassistent, Flensborg

Dahl, Holger, kæmner, Augustenborg

Frisk, Anders, snedkermester, Gram

Frost, Jens, museumsinspekt $\emptyset r$, Åbenrå $\dagger$

Fyens Stifts Læseforening, Odense

Gotthardsen, Michelle, skoleleder, Møllebro pr. Flensborg

Hansen, Eschild, gårdejer, Stevninggård

Hansen, Hans, konsulent, Åbenrå $\dagger$

Hansen, Sigurd Brandt, friskolelærer, Lunde

Hansen, Thomas, gårdejer, Store Solt

Hanssen, Sv. A., gårdejer, Norremolle $\dagger$ 
Hersb $\varnothing$ l, fhv. stationsforstander, Åbenrå

Jefsen-Christensen, $H$., fhv. landstingsmand, $\mathrm{H} \phi$ gsbro $\dagger$

Jensen, Christian, gårdejer, Skovby, Als

Jensen, Rigmor, lærerinde, Åbenrå

Jørgensen, Hakon, lærer, Flensborg

Knudsen, Erik H., frimenighedspræst, Hornum

Københoved bogsamling

Larsen, Harald, lærer, Flensborg

Larsen, Sigrid, konsulent, Harreslevmark

Lindegaard, M. C., biskop, Ribe $\dagger$

Ludvigsen, Carl J., præest, Åbenrå $\dagger$

Lüddens, Wilh., lærer, Tumby $\dagger$

Mees, H. J., lærer, Flensborg

Michael, C., børnehaveleder, Haderslev $\dagger$

Moltke, Carl, generalmajor, Charlottenlund $\dagger$

Moos, Holger, adjunkt, Åbenrå

Moos, P. H., pastor emer., Åbenrå

Nielsen, Marie, frk., Søes

Nissen, Jeppe, købmand, Vester Sottrup

Petersen, Anton, gårdejer, Langbjerg

Petersen, Daniel, godsejer, Vesterholt ved Husum

Rattenborg, Karen, bibliotekar, Flensborg

Schmidt, Nis, gårdejer, Broballe

Schmidt, P., restaurat $\varnothing r$, Sønderborg

Schøler, Anker, skolgleder, Garding
Simonsen, Christen, handelsmand, Sdr. Hygum †

Skov, A. L., rentier, Bevtoft $\dagger$

Tholle, Johs., havearkitekt, København $\mathbf{F}$

Thomsen, A. Jessen, assurand $\varnothing r$, Åbenrå

Thomsen, Lars Boe, repræsentant, Assens

Thorndahl, P., læerer, Haurum skole pr. Flemming

Weber, J., landmand, Damholm pr. Ølsby

Vollertsen, Ernst, seminarieelev, Ribe

Tilgangsliste

ABBENR AMT

Åbenrả by:

Andersen, Peter, købmand

Andersen, Skifter, direkt $\phi r$

Andresen, Carl, civilingeni $\varnothing r$

Andresen, Peter, boghandler

Bisgård, Frode, cand. mag.

Bjerre, S., direkt $\varnothing r$

Bjerring, Carl, bagermester

Brandi, Aa., bankassistent

Bygballe, A., sagfører

Callesen, Ingvard, arkitekt

Christensen, Johannes C., direktør

Cleemann, Harald, skibsmægler

Damberg, Peter, isenkræmmer

Faber, Poul, apoteker

Fabricius, M., grosserer

Gimbel, P., direktør

Hansen, Hans M., købmand

Hansen, Marie, fru

Heidemann, Hans Georg, prokurist

Hoffmann-Madsen, C., sognepræst

Jessen, Frik, købmand 
Jessen, Johan, købmand Jessen, Olaf, købmand Jessen, Peter, købmand

Jørgensen, Nis, sparekasseassistent

Lampe, Jens, kommunelærer Larsen-Ledet, Clement, redakt $\emptyset r$ Lauridsen, Jørgen, købmand Lyck, Herbert, direkt $\phi r$ Lyck, Svend, grosserer Mathiesen, Adolf, havnefoged Møller, Claus, fabrikant

Nicolaisen, Wilhelm, barbermester

Nielsen, Anton, købmand

Nielsen, Holger, købmand

Nielsen, Vitus, statsaut, revisor Paulsen, Alfred, maskinhandler Petersen, Jørgen, filialbestyrer

Petersen, Tage, forretningsf $\emptyset$ rer

Philippsen, A., kommunelærer

Riis-Antonsen, møbelhandler

Ross, W., kontorchef

Scherrebeck, Jacob, kontorass.

Schmidt, Hans, prokurist

Schultz, Jørgen, distriktschef

Sylvestersen, Harald, amtstuefuldmægtig

Sørensen, Niels, købmand Thisted, V. Gjeding, dommer Tofft, L,. landsretssagf $\emptyset r e r$ Tolstrup, Hans, bankassistent, Unna, G. W., fru dr.

Vagn-Hansen, C. A., amtmand

Ziethen, B. A., malermester

\section{Bov sogn:}

Andersen, W., overkontrollør, Padborg

Bay, R., forretningsf $\phi r e r$, Padborg

Bergholt, I., toldvagtmester, Padborg
Carlsen, G., kontorist, Frøslev savværk

Fejrskov, P., politibetjent, Padborg

Gammelgård, Sven, førstelærer, Kollund

Gregersen, B., overassistent, Padborg

Grevsen, N. P., toldbetjent, Padborg

Jensen, Jacob, grænsevagtmester, Padborg

Kudsk, P., overassistent, Padborg

Larsen, Th. toldassistent, Padborg

Lund-Jensen, N. P., toldassistent, Padborg

Nielsen, S. G., trafikkontrollør, Padborg

Petersen, M., politiassistent, Padborg

Schytt, O., toldforvalter, Padborg

Sonne, E., kæmner, Padborg

Egvad sogn:

Bruhn, Wilhelm, gårdejer, Hørlyk

Haugaard, Samuel Koch, landmand, Nr. Hostrup

Iversen, Jørgen, gårdejer, Horsbyg

Johnsen, Nis, gårdejer, Nr. Hostrup

Petersen, Peter H., gårdejer, Horsbyg

Ensted sogn:

Hansen, Holger, gårdejer, Tinggård 
Michelsen, Mads, skoleelev,

Lundsbjerg

\section{Felsted sogn:}

Lauesgaard, Viggo, gårdejer, Kidding

Todsen, Chr. P., Assenholm

Gråsten sogn:

Bleshøj, Jørgen, urmager

Kværs sogn:

Lauridsen, Frode Møller, sogneprast

Lфjt sogn :

Petersen, Nis, smedemester, Bodum

Rinkenæs sogn:

Nielsen, Laurits, gårdejer, Buskmose

Uge sogn:

Kjer, Kristian N., f $\emptyset$ rstelærer

Varnæs sogn:

Christiansen, Rasmus, k $\phi$ bmand, Bovrup

Staugaard, Hans Peter, gårdejer, Bovrup

\section{Øster Løgum sogn:}

Itske, Ingeborg, lærerinde, Hovslund

\section{HADERSLEV AMT}

Haderslev by:

Ahring, Hermann, forretningsfører
Albeck, Wilhelm, læge

Christiansen, G., læge, fru

Clausen, Gertrud Balslev, frk.

Hansen, E. Lytved, lærer

Hansen, Sv. Irgens, redaktionssekretær

Jensen, Kirsten, bibliotekar

Jørgensen, Poul A., lærer

Møller, M., adjunkt

Nielsen, Axel, seminarielærer

Nygaard, Marie, bibliotekar

Obel, Astrid, bibliotekar

Petersen, Gottlieb, kontorassistent

Petersen, Peter H., kontorassistent

Pugdahl, Søs, sekretær, fru

Schmidt, frk.

Schmidt, H. P., overtoldassistent

Schou, Poul, stiftsprovst

Wielandt, A., adjunkt

Agerskov sogn:

AppeI, Andreas, gârdejer, Rangstrup

Biblioteket, Agerskov

Bjorholm, Jes, lanclmand, Rangstrup

Christensen, Damgaard, lærer, Rangstrup

Gram, Lorens, landmand, Agerskov

Hansen, Anna, fru, Bovlund

Hørlyck, Laur., gårdejer, Rangstrup

Knudsen, Didde, fru, Rangstrup

Knudsen, Kristen, landmand, Galsted

Lauenborg, P., direktør, Agerskov

Poulsen, Troels Refslund, gårdejer, Bovlund

Thim, Jørgen, Mellerup

Toft, P. AppeI, dyrlage, Rangstrup 
Warncke, lærer, Rangstrup

Westergaard, Bunde, landmand, Galsted

\section{Aller sogn:}

Biblioteket, Aller

Bevtoft sogn:

Dinesen, Jens, gårdejer, Hjartbro

Branderup sogn:

Andersen, Holger, gårdejer, Rurup

Nielsen, Anton, landmand, Rurup

Petersen, Peter, førstelærer,

Rurup skole

Fjelstrup sogn:

Skøtt, Hans Chr., forpagter, Vadbjerggård

Biblioteket, Fjelstrup

Frørup sogn:

Hansen, Niels Ebbesen, gårdejer, Bramsgård

Gram sogn:

Christiansen, Steen, sognepræst, Gram

Hansen, Jes, boghandler, Gram

Nielsen, Johannes, lærer, Tiset

Schultz, K., førstelærer, Vester

Lindet

Grarup sogn:

Jørgensen, Peter, graver, Grarup

Halk sogn:

Hansen, Mogens, gårdejer, Hejsager
Hammelev sogn:

Lorenzen, Chr., førstelærer, Hammelev

Hjerndrup sogn:

Biblioteket, Hjerndrup

Høyer, Aage, gårdejer, Juhlsminde

Mikkelsen, H., gårdejer,

Kjerulfsminde

Jels sogn:

Büchert, Peter, kontrolassistent, Farris st.

Wolf, Math. J., gårdejer, Søgård pr. Farris

Lintrup sogn:

Jensen, C., lærer, Mejlby skole

Christensen, Sigfr., sognepræst, Lintrup

Magstrup sogn:

Sørensen, Sigurd, tømrermester, Magstrup

Moltrup sogn:

Bjerre, Johs., sognepræst, Moltrup

Nustrup sogn:

Biblioteket, Nustrup

Oksenvad sogn:

Biblioteket, Oksenvad

Otte, Mads, gårdejer, Stursb $\varnothing 1$

Skodborg sogn:

Holm, Jacob, dyrlæge, Skodborg 
Skrave sogn:

Andersen, Ejnar Rostgaard, gårdejer, Københoved

Biblioteket, Skrave

Boesen, P., fhv. førstelærer, Københoved

Hansen, Kristian A., gårdejer, Krogstrup

Jensen, Hans, forpagter, Københoved

Jessen, Peter Neergaard, sognepræst, Skrave

Kjær, Niels, murermester, Københoved

Lydiksen, Marie Kjestine, Københoved

Mandøe, Niels, lærer, Skrave

Tybjerg, F., uddeler, Københoved

$\emptyset$ stergaard, Niels, gårdejer,

Københoved

\section{Sommersted sogn:}

Biblioteket, Sommersted

Biblioteket, Over Lerte skole

Biblioteket, Neder Lerte skole

Fræhr, Hans G., manufakturhandler, Sommersted

Skjøth, Hans, gårdejer, Solskjær

\section{Starup sogn:}

Nielsen, Jacob Finderup, førstelærer, Starup

Stepping sogn:

Biblioteket, Stepping

Hansen, Sejr Buchhave, mejeribestyrer, Stepping

Tirslund sogn:

Hansen, Jørgen, førstelærer, Tirslund

\section{Toftlund sogn:}

Nielsen, Kr., dyrlæge, Toftlund

Rossen, H. C., sognepræst, Toftlund

Sloth, H., skoleinspekt $\varnothing r$, Toftlund

Thygesen, K., læge, Toftlund

Wind, B. R., f $\varnothing$ rstelærer, Stenderup

Vedsted sogn:

Biblioteket, Arnitlund

Lisberg, Lars, lærer, Over Jerstal

Lund, A. P., lærer, Abkær

Pedersen, Albert, førstelærer, Vedsted

\section{Vojens sogn:}

Andresen, Knud, lærer, Vojens Jensen, Chr., tømrermester, Vojens

Jensen, Ingrid, bankbestyrer, Vojens

Michaelsen, Christian, forpagter, Paulsbjerg

Poulsen, Anton, guldsmed, Vojens

Schøning, Chr. F., isenkræmmer, Vojens

Schøning, Hans, prokurist, Vojens

Thomsen, Thøger B., arkitekt, Vojens

Winterskov, C. T. købmand, Vojens

\section{Vonsbæk sogn:}

Skau, Laurids, gårdejer, Orby

$\emptyset$ pby sogn:

Abildgren, J., lærer, Kvistrup Rasmussen, lærer, Hajstrup 


\section{Astrup sogn:}

Raun, Nis, forpagter,

Nederbygård

\section{SøNDERBORG AMT}

Sønderborg by:

Carøe, Fin, landsretssagf $\varnothing r e r$

Grove-Stephensen, F. S., sagf $\phi r e r$

Hellesen, Sv. A., kontorchef

Huhle, Robert, redakt $\varnothing \mathbf{r}$

Schlanbusch, Poul, sparekassebogholder

Schmidt, Gudrun Brink, økonoma

Nybøl sogn:

Jørgensen, Christian, f $\emptyset$ rstelærer, Nyb $\varnothing 1$

\section{Sottrup sogn:}

Jacobsen, Hans Andr., stud. theol., Vester Sottrup

\section{TONDER AMT}

Tфnder by:

Buch, Chr., bagermester

Bølling-Ladegård, E., sagfører

Christensen, Inger, fru

Jensen, A., premierløjtnant

Michaelsen, B., tandlæge

Posselt, EIse, fru

Rosenvold, Holger, arkitekt

Røgilds, Jens, seminarieelev

Sünksen, Sv. E., grosserer

Sørensen, Christiane, seminarielærerinde

Willumsen, Henning, fuldmægtig

\section{Arrild sogn:}

Enevoldsen, B., overbetjent,

Renbæk
Gyldenkærne, Aksel, lærer, Arrild skole

Præstiin, M. B., førstelærer, Arrild skole

Rasmussen, S., skovfoged, Lindet skov

Skovenborg, Johs., lærer, Hønning skole

Sørensen, V., lærer, Roost skole

Ballum sogn:

Lindholm, Juliane, fru, Bodsbøl

Lorenzen, Cathrine, gårdejerske, Ballum

Brede sogn:

Petersen, Thomas, lærer,

Bredebro

Refshauge, Gudrun, sygeplejerske, Bredebro

Styrk, Anders, gårdejer, Borg mark

Brøns sogn:

Freudendahl, J. S., mekaniker, Brøns

Burkal sogn:

Eg-Larsen, forstander, Rends efterskole

Lyksholm, Kaj, sognepræst, Burkal

Hjerpsted sogn:

Nielsen, Otto, landmand, Koldby

Hviding sogn:

Jacobsen, Axel, sognepræst, Hviding

Hфjst sogn:

Thorup, W. S., lærer, Alslev 
Løgumkloster flække:

Bekke, Ferdinand, rentier

Kjems, Holger, farmaceut

Ravn, Marie, skoleinspekt $\emptyset r$

Løgumkloster landsogn:

Bærenholdt-Jensen, Gregers, lærer, Ellum

Møgeltønder sogn:

Borg, Chr. C. M., seminarieelev, Møgelt $\emptyset$ nder

Gregersen, Viggo, kommunekasserer, Møgeltønder

Iversen, Hans, gårdejer, Bønderby

J $\varnothing$ rgensen, K. M., sognepræst, Møgeltønder

\section{Rabsted sogn:}

Beckmann, Viggo, landmand, Korup

Jensen, K. Riisberg, pastor, Rabsted

Mathiesen, Niels, medhjælper, Korup

Sohmidt, Hans, forpagter, Hejsel

Røm $\phi$ sogn:

Jørgensen, Christian, sognepræst, $\operatorname{Røm} \emptyset$

Skast sogn:

Refslund-Hansen, Marten, gảrdejer, Skastgård

Spandet sogn:

Lustrup, Niels H., rentier, Spandet
Tinglev sogn:

Andersen, Chr., sognepræst, Tinglev

Ubjerg sogn:

Krebs Lange, lærer, Sæd Rasmussen, A., sognepræst, Ubjerg

Vodder sogn:

Krogh, P. Mousten, værkmester, Nørregård, Renbæk

\section{SYDSLESVIG}

Egernførde kreds:

Bak, Jens, lærer, Egernf $\emptyset$ rde

Call $\varnothing$, Iver, direkt $\varnothing r$, Egernf $\phi$ rde Jensen, Jacob Kruse, lærer, Ascheffel

Jørgensen, Jørgen, lærer, Egernf $\emptyset r d e$

Lorenzen, Christian, lærer, Egernf $\emptyset$ rde

Munk-Pedersen, Else, skoleleder, Egernf $\varnothing$ rde

Ejdersted kreds:

Eggers, Jacob, landmand, Augusten Kog

Flensborg by:

Balle, Jens, dr.

Christensen, Eva, lærerinde

Christensen, Jes, rektor

Futtrup, Anders, Dansk ungdomshjem

Eckell-Jessen, A. P., ingeniør

Henningsen, Hans, skibsmægler

Jessen, Fr. prokurist

Jessen, Marie, lærerinde

Matlok, Norbert, boghandler 
Nielsen, Vibeke, fru

Schlesinger, M., fhv. lærerinde, frk.

Schütt, Christian, bankdirektør Tychsen, Hermann, rektor

Weiss, Anna Marie, fru

Flensborg kreds:

Futtrup, Jens, seminarieforstander, Hanved

Lieb, Axel, skoleleder, Flensborg Sporskifte

Ohlsen, Oluf, grosserer, Lyksborg

Petersen, Ellen Margr. Busk, børnehavelærerinde, Harreslevmark

Reinholdt, Chr., lærer, Langbjerg

Husum kreds:

Grundmann, Hilde, frk., Husum

Rendsborg kreds:

Uhrenholdt, S $\phi r e n$, rektor, Rendsborg

\section{Slesvig kreds:}

Albertsen, Sigurd Boye, overlærer, Kappel

Breddam, Laur., lærer, Slesvig Hansen, Christa, fru, Ølsbyskov Holm, Frants, skoleleder, Nyberend
Jørgensen, Anne, lærerinde, Sdr. Brarup

Jørgensen, Helga, overlærer, Slesvig

Kall, Ilse, fru, Tolk-Skovby

Lindholm, Andr., skoleleder, Tolk

Lüddens, Elisabeth, fru, Satrup

Meinhardt, Elly, frk., Satrup

Nielsen, Nina, sekretær, Slesvig

Søe-Petersen, Sv., skoleleder, Damholm

Weber, J., landmand, Damholm

Wehlitz, Hellmut, lærer, Hostrup

\section{STOR-KøBENHAVN}

Hansen, Johs., stud. med., Nr. Alle 75 , København $\emptyset$.

Hoffmeyer, Johs., lektor, Pilealle 17, Holte

Plum, D., fuldmægtig, S $\varnothing$ borg Hovedgade 149, S $\phi$ borg

\section{ØVRIGE DANMARK}

Heilesen, Henning, arkivar, Viborg

Nielsen, E., civilingeniør, Holbæk

Nordentoft, Jens Munck, overlæge, Ålborg

Petersen, Johannes Busk, journalist, Holstebro

Troelsen, Svend B., gårdejer, Vester Vedsted

Ved redaktionens slutning var medlemstallet steget til over 1650 . 


\section{Vore tillidsmænd}

\section{ÅBENRÅ AMT}

Ảbenrå by:

Clausen, P., skoleinspekt $\varnothing r$, Rugkobbelskolen

Flade, K. A., arkitekt, Kystvej 48

Jacobsen, Holger, overassistent, Ramsherred 49 a

Bedsted sogn:

Gasberg, P., lærer, Øster Terp skole, Bedsted L $\varnothing$

Mathiesen, A., f $\phi$ rstelarer, Bedsted skole, Bedsted L $\varnothing$

Bjolderup sogn:

Holdt, Jacob, lærer, Bjolderup pr. Bolderslev

Bov sogn:

Harrits $\emptyset$, Axel, sognepræst, Bov pr. Padborg

Wortmann, Andr., arbejdsmand, Søndermosevej, Padborg

Egvad sogn:

Petersen, Peter Jepsen, gårdejer, $\emptyset$ bening pr. Hellevad

Ensted sogn:

Fenger, Jørgen, sognepræst, Ensted pr. Åbenrå

Felsted sogn:

Petersen, H., lærer, Felstedskov pr. Varnæs
Grảsten sogn:

Bjerre, A. M., politimester, Gråsten

Nissen, fru bankdirekt $\varnothing r$, Graasten Bank

Hellevad sogn:

Hansen, Peter P., lærer, Hellevad

Hjordkar sogn:

Bøgh, Chr., sognefoged, Hjordkær

Holb $\phi l$ sogn:

Petersen, P. J., provst, Holbøl pr. Tørsbøl

Kliplev sogn:

Zachariassen, sogneprast.

Kliplev

Løjt sogn:

Jepsen, J., gårdejer, landbrugskandidat, LI. Strandgård pr. Åbenrå

Rinkenæs sogn:

Nørgaard, Kr., forstander, Årsbjerg pr. Rinkenæs

Rise sogn:

Larsen, N. kommunesekretær, Rørlekro 
Uge sogn:

Jørgensen, H. P., rentier, Olmersvold pr. Tinglev

Varnes sogn:

I.auersen, Jens Chr., kontrolassistent, Bovrup

Schrøder, Urban, sognepræst, Varnæs

\section{Øster Løgum sogn:}

Callø, Mads, gårdejer, Genner Holdt, Jes M., lærer, Rugbjerg pr. Hovslund

\section{HADERSLEV AMT}

Haderslev by:

Eriksen, Hans E., bibliotekar, Hjortebrovej 30

\section{Åstrup sogn:}

Raun, Nis, forpagter, Nederbygård, Åstrup pr. Haderslev

Agerskov sogn:

Junker, Alfred, slagtermester, Agerskov

Petersen, Andreas, k $\varnothing$ bmand, Rangstrup pr. Agerskov

Rolskov, E., lærer, Gestrup pr. Toftlund

\section{Aller sogn:}

Boesen, gårdejer, Stubbom pr. Fjelstrup

\section{Bevtoft sogn:}

Dinesen, Jens, gårdejer, Bevtoft Nissen, Peter Jessen, gảrdejer, Strandelhjørn pr. O. Jerstal

\section{Branderup sogn}

Thomsen, Jacob, sogneradsform., Branderup mølle pr. Branderup

\section{Christiansfeld:}

Madsen, Johan, borgmester, Christiansfeld

Fjelstrup sogn:

Hansen, Jes, gårdejer, Fjelstrup

Fole sogn:

Filtenborg, P. P., provst, Fole

Frørup sogn:

Hansen, Niels Ebbesen, gardejer, Bramsgård, Frørup pr. Stepping

Gram sogn:

Weber, Peter, vognmand, Gram

Grarup sogn:

Jørgensen, Peter, graver, Grarup pr. Haderslev

Halk sogn:

Eriksen, Erik, gårdejer, Halk pr. Hejsager

Hammelev sogn:

Lorenzen, Chr., lærer, Hammelev

Herndrup sogn:

Hansen, Peter, gårdejer, Hjerndrup pr. Christiansfeld

Hjerting sogn:

Hansen, Ejnar, gårdejer, Bjørnekær pr. Rødding.

Friis, Hans, lærer Hjerting pr. Rødding 
Hoptrup sogn:

Lauritsen, H. P. forstander, Hoptrup

Hygum sogn:

Fokdal, Hans, pens. lærer, Fæsted pr. Sdr. Hygum

Jels sogn:

Grønbjerg, Jens, f $\varnothing$ rstelærer, Grønnebæk pr. Jels

Jegerup sogn:

Eriksen, M., førstelæerer, Jegerup pr. Yojens

\section{Lintrup sogn:}

Jensen, Hans Søholm, Tornumgård pr. Lintrup

S $\emptyset$ ndergaard, K. Lykke, f $\emptyset$ rstelærer, Dover pr. Lintrup

Magstrup sogn:

Dalberg, E. sogneprast, Magstrup pr. Simmersted

Moltrup sogn:

Bjerre, Johs., sognepræst, Moltrup pr. Haderslev

Nustrup sogn:

Sørensen, Hans M. lærer, St. Nustrup

Rødding sogn:

Fink Hakon, gârdejer, Brændstrup pr. Gram

Madsen, Hans, redakt $\varnothing r$, Rødding
Skodborg sogn:

Hansen, Chresten, gårdejer, Højvang, Skodborg

Otto, Peter P., gårdejer, Gejlager pr. Skodborg

Skrave sogn:

Mathisen, H., mejeribestyrer, Skrave pr. Skodborg

Ferslev, M. P., malermester, Københoved pr. Skodborg

Skrydstrup sogn:

Madsen, Chresten, sekretær, Skrydstrup pr. Vojens

Sommersted sogn:

Michelsen, R., dyrlæge, Sommersted

Starup sogn:

Nielsen, J. Finderup, f $\phi$ rstelærer, Starup pr. Haderslev

Stepping sogn:

Nissen, M. sognepræst, Stepping

Toftlund sogn:

Johansen, E., boghandler, Toftlund

Tyrstrup sogn:

Bancke, Viggo C., degn, Tyrstrup pr. Christiansfeld

Vedsted sogn:

Lomholt-Thomsen, V., sognepræst, Vedsted pr. O. Jerstal 


\section{Vilstrup sogn:}

Kloppenborg-Skrumsager, S. gårdejer, Kanekær pr. Sdr. Vilstrup

Vojens sogn:

Aalling, J. Jensen, arkivar, Vojens

Holm, Tage, sognepræst, Vojens

Vonsbæk sogn:

Skau, Laurids, gårdejer, Ørby pr. Vonsbæk

$\emptyset$ sby sogn:

Sørensen, Simeon, gårdejer, Hajstrup pr. Øsby

$\emptyset$ ster Lindet sogn:

Skau, Jens, forpagter, Nygård pr. $\emptyset$. Lindet

\section{SøNDERBORG AMT}

Sønderborg by:

Huhle, Robert, redakt $\varnothing$ r, Rylen 8, S $\varnothing$ nderborg

Slettebo, Jørgen, museumsinspektør, Slottet, Sønderborg

Asserballe sogn:

Christensen, Ernst, gårdejer, Sædmosegård, Asserballe pr. Augustenborg

Hans, Hansen, aftægtsmand, Asserballe pr. Augustenborg

Augustenborg sogn:

Jørgensen, Jørgen, borgmester, Augustenborg

Nielsen, Hans P., pensionist, Osbækvej 1, Augustenborg
Broager sogn:

Hollensen, Svend, gårdejer, Mølmark pr. Broager

Korse, Aug., forretningsf $ø r e r$, Vestergade 35, Broager

Dybbøl sogn:

Ruge, Emil, keramiker, Dybb $\varnothing 1$ mølle pr. Sønderborg

Havnbjerg sogn:

Jørgensen, Jacob, gårdejer, Brandsb $\emptyset 1$ pr. Nordborg

Rieck, J $\varnothing$ rgen R., vagtchef, Lærkevej 18 , Langes $\varnothing$ pr. Nordborg

Skov, Chr., gårdejer, Lavensby pr. Nordborg

Horup sogn:

Jessen, Rita, fru, Eblebjerg pr. Hørup

Kegnæs sogn:

Andreasen, Georg, lærer, Sønderby skole, Kegnæs

Lysabild sogn:

Lassen, Chr., aftægtsmand, Tinggård, Skovby

Madsen, H. C., sognepræst, Lysabild

Nordborg sogn:

Hansen, Jes, lærer, Holm pr. Nordborg

Jensen, R. M., lærer, Holm skole pr. Nordborg

Notmark sogn:

Thomsen, Hans, gårdejer, Bommerlund pr. Fynshav

Therkelsen, Frede, forstander, Danebod pr. Fynshav 
Sottrup sogn:

Bonefeld, Olav, gårdejer,

Snogbæk pr. V. Sottrup

Tandslet sogn:

Roesdahl, H., læge, Tandslet

Ulkebดl sogn:

Hansen, Martin, sognepræst, Ulkeb $\emptyset 1$ pr. Sønderborg

Ullerup sogn:

Clausen, Peter, Lundsmark pr. V. Sottrup.

\section{TØNDER AMT}

Tonder by:

Christiansen, W, viceskoleinspekt $\phi r$, Brorsonsvej 37, Tønder

Fan $\varnothing$, Knud, adjunkt, Frilandsvej 21, Tønder

\section{Abild sogn:}

Andersen, Hans, gårdejer, Kongsbjerg pr. Tønder

Arrild sogn:

Madsen, Jeppe, gårdejer, Roostgård, Arrild

\section{Ballum sogn:}

Præstiin, H., f $\emptyset$ rstelærer, Bodsbøl pr. Ballum

Brede sogn:

Holdt, J., provst, dr. theol., Brede

Nissen, Søren, gårdejer, Harris pr. Bredebro
Brфns sogn:

Andersen, P. Obeling, gårdejer, Virkelyst, Brøns

Burkal sogn:

Leick, Willy, førstelærer, Lydersholm pr. Jejsing

Bylderup sogn:

Knudsen, Nis, lærer, Bylderup

Daler sogn:

Flint, H., førstelærer, Daler pr. Daler- $\emptyset$ sterby

Døstrup sogn:

Schmidt, Cornelius, gårdejer, Døstrup

Emmerlev sogn:

Larsen, L. A., pens. f $\emptyset$ rstelærer, Emmerlev pr. Højer

Hjerpsted sogn:

Brodersen, C., bagermester, Hjerpsted pr. Højer

Hostrup sogn:

Maibøll, C., pens. lærer, Jejsing

Hviding sogn:

Warming, M., gårdejer, Råhede pr. Hviding

Højer flokke:

Hansen, Jens Mollerup, lærer, Højer

Højer landsogn:

Kristensen, Iver, landmand, Rudbøl pr. Højer 
II бirup sogn:

Hansen, P., lærer, Højrup pr. Arnum

Hojst sogn:

Hansen, Johs., købmand, Ellehus pr. Jejsing

Thorup, W., lærer, Alslev pr. Ø. Højst

Løgumkloster flække:

Thomsen, P. P., kæmner, Løgumkloster

Mjolden sogn:

Hage Petersen, rentemodtager, Mjolden pr. Døstrup Sdrjl.

Møgeltønder sogn:

Nielsen, N. Juhl, lærer, Møgelt $\varnothing$ nder

Nr. Løgum sogn:

Friis, Claus J., gårdejer, Løgumgård pr. Løgumkloster Refslund Poulsen, Jens, lærer, Ny Bjerndrup pr. Løgumkloster

Rabsted sogn:

Christensen, S. N., f $\varnothing$ rstelærer, Rabsted

\section{Randerup sogn:}

Brodersen, Anders, landmand, Randerup pr. Ballum

\section{Rejsby sogn:}

Petersen, Niels, forpagter, Kærbølling, Rejsby
Roager sogn:

Gad, Uffe K., gårdejer, Ravnholt pr. Roager

$R \phi m \phi:$

Schmidt, Alfred, købmand, Kongsmark

Skast sogn:

Nielsen, Jørgen, lærer, Skast pr. Ballum

Skærbæk sogn:

Fromsejer, skovrider, Skærbæk

Spandet sogn:

Schmidt, Peter, gårdejer, Spandetgård, Spandet pr. Arnum

Tinglev sogn:

Schmidt, Laur., lærer, Bajstrup pr. Tinglev

Visby sogn:

Schmidt-Nielsen, K., lærer, Visby

Vodder sogn:

Kjær, Hans, gårdejer, Gånsager pr. Frifelt

\section{SYDSLESVIG}

Flensborg:

Madsen, Thomas, lektor, Duborgskolen

Angel:

Petersen, H. F., pastor, Satrup/ Angel

Büchert, Nic., lærer, Husby/ Angel 
Midtlandet:

Paulsen, Erik, Musbæk pr. Harreslev

Andresen, Katrine, fru, Hyllerup, Flensborg Land

Vestlandet:

Dinsen Hansen, skoleinspekt $\emptyset r$, Nibøl
Schubert, Lars, amtssekretær, Husum

Syd:

Kürstein, Poul, bibliotekar, Plessensgade 1 a, Slesvig

Hansen, Andreas, lærer, Vestermølle, Rendsborg Nørreamt 
HISTORISK SAMFUND FOR SØNDERJYLLAND

har folgende styrelse:

formand: arkivar Peter Kr. Iversen, Ảbenrå

kasserer: fuldmregtig Olav Christensen, Haderslev

sekretær: læerer Chr. Stenz, Âbenrả

amtsudvalgsformand :

gdr. Ernst Christensen, Asserballe skoleinspektør P. Clauseu, Åbenrå pastor Tage Holm, Vojens pastor H. F. Petersen, Satrup, Angel gdr. Cornelius Schmidt, Dostrup

styrelsesmedlemmer i $\phi v$ rigt:

viceskoleinspektør. Werner Christiansen, 'Tønder

adjunkt Knud Fanф, Tønder

professor, dr. phil. Troels Fink, Århus provst, dr. theol. Jens Holdt, Brede landsarkivar Johan Hvidtfeldt, Viborg fhv. højskoleforstander Hans Lund, Tanderupgård museumsinspektør Hans Neumann, Haderslev

acesmedlemmer:

thv. museumsinspektør,

dr. phil. M. Mackeprang, København, og fhv. amtslage, dr. H. Lausten-Thomsen, Åbenrå

formanden, kassereren og sekretæren dammer forretuingsudvalg

museumsinspektør J. Slettebo, Sønderborg, fungerer som hjwelpesekreter redaktionsadresser :

Sønderjyske årbøger: Knud Fanø, Frilandsvej 21, 'l'onder

Sønderjysk månedsskı ift :

Werner Christiansen,

Brorsonsvej 37, Tønder

Skriftrækken: Peter Kr. Iversen, Kystvej 10, Ảbenră

kassererens adresse:

Olav Christensen, Christiansfeldvej 30, Haderslev, giro : 42682

celdre årbøger og skrifter bestilles hos kassereren

Sønderjysk månedsskrift bestilles hos Werner Christiansen, Brorsonsvej 37, Tønder

medlemsbidrag, hvorfor medlemmerne modtager Sønderjyske årbøger, ndg $\phi \mathbf{r} 7,50 \mathrm{kr}$. árligt + porto

indmeldelser modtages af alle styrelsesmedlemmer og de lokale tillidsmænd.

Sønderjyske ảrbøger i konmission hos Danske Boghandleres Kommissionsanstalt, Nyropsgade 19, Kobenhavn $\mathrm{V}$. 
